\title{
Petrology and geochemistry of the Kingston complex - a bimodal sheeted dyke suite in southern New Brunswick
}

\author{
G.N. Eby ${ }^{1}$ and K.L. Currie ${ }^{2}$ \\ 'Department of Earth Sciences, University of Massachusetts, Lowell, Massachusetts 01854, U.S.A. \\ ${ }^{2}$ Geological Survey of Canada, 601 Booth Street, Ottawa, Ontario K1A OE8, Canada
}

\author{
Date Received March 5, 1993 \\ Date Accepted May 25, 1993
}

\begin{abstract}
The lower Silurian Kingston complex of southern New Brunswick consists of metamorphosed sheeted bimodal dykes, exposed over a strike length of more than $100 \mathrm{~km}$ and a width of 3 to $8 \mathrm{~km}$. The southwestern portion of the complex is bounded by major mylonite zones and the northeastern portion is bounded by brittle faults.

Mafic dykes consist of actinolite-plagioclase rocks with tholeiitic chemistry, typical of continental margin basalts. Salic dykes are rhyolitic or microgranitic, and have a chemistry typical of $A_{2}$-type granitoids which are emplaced in post-collisional or post-subduction tensional environments. Despite the obvious extensional setting, the mafic dykes are chemically similar to older basalts in the Saint John region, which were emplaced in a subduction setting. Their chemistry apparently reflects the source of the melts (underplated lithosphere) rather than the tectonic setting.

The Kingston complex marks both the initiation and southeastern limit of major Siluro-Devonian magmatism in southern New Brunswick. Modelling suggests that emplacement of the complex took at least 2 to 3 million years during which heat input into the crust remained relatively low. Subsequent increase in the heat input during Silurian and Devonian time produced large-scale melting, pluton emplacement and metamorphism of the Kingston complex. Heating probably resulted from delamination of the crust which allowed hot asthenosphere to impinge on the lower crust. The Kingston complex is a unique remnant indicating the origins and nature of magmatism along major transcurrent faults near the edge of the Avalon zone of the Appalachian orogen.
\end{abstract}

Le complexe de Kingston du Silurien inférieur du sud du Nouveau-Brunswick consiste en un essaim de dykes bimodal métamorphisé, exposé sur une longueur de plus de $100 \mathrm{~km}$ et une largeur de 3 à $8 \mathrm{~km}$. La partie sud-ouest du complexe est bordée par des zones de mylonite majeures et la partie nord-est est bordée de failles fragiles.

Les dykes mafiques consistent en roches à actinote-plagioclase de composition tholéiique, typiques des basaltes de marges continentales. Les dykes felsiques sont rhyolitiques ou microgranitiques et ont une composition typique des granitoïdes de type- $A_{2}$ qui sont mis en place dans des environnements d'extension post-collisionnelle ou postsubduction. Malgré le contexte extensionnel évident, les dykes mafiques sont chimiquement similaires aux basaltes plus anciens de la région de Saint-Jean, qui furent mis en place dans un environnement de subduction. Leur composition reflète apparemment la source des magmas (lithosphère épaissie par des intrusions à sa base) plutôt que le contexte tectonique.

Le complexe de Kingston marque à la fois le début et la limite sud-est du magmatisme Siluro-dévonien majeur dans le sud du Nouveau-Brunswick. La modélisation suggère que l'emplacement du complexe prit au moins 2 à 3 millions d'années durant lesquelles l'apport de chaleur dans la croûte resta relativement bas. Des augmentations subséquentes dans l'apport de chaleur pendant le Silurien et le Dévonien produisirent une fusion à grande échelle, l'emplacement de plutons et le métamorphisme du complexe de Kingston. La chauffe a probablement résulté de la délamination de la croûte qui permit à l'asthénosphère chaude d'affecter la croûte inférieure. Le complexe de Kingston est un vestige unique indiquant les origines et la nature du magmatisme le long des failles de décrochement majeures près de la bordure de la zone d'Avalon de l'orogène appalachien.

[Traduit par la rédaction]

\section{INTRODUCTION}

Large igneous complexes composed entirely of subparallel dykes are a rare geological phenomenon most commonly formed at oceanic spreading centers (mafic sheeted dyke complexes). A sheeted dyke complex with bimodal composition and different origin occurs in southern New Brunswick. The complex is exposed over an area of $500 \mathrm{~km}^{2}$ and probably underlies at least twice that area, and is bounded by major transcurrent shear zones. In this paper we describe the geochemistry and petrology of this complex, and put forth a model for the emplacement of the bimodal dykes.

\section{Geologic Setting}

The scale and sheeted nature of the Kingston complex were first recognized by Currie (1984), but dykes forming parts of the complex have been studied since pioneering work by Cumming (1916), with notable contributions by Helmstaedt (1968), O'Brien (1976), Rast and Dickson (1982), Dickson (1985), McCutcheon and Ruitenberg (1987), and McLeod and Rast (1988). Outcrop of the Kingston complex extends nearly $100 \mathrm{~km}$, from Beaver Harbour to Hampton (Fig. 1), with an exposed width varying from $3 \mathrm{~km}$ at Beaver 

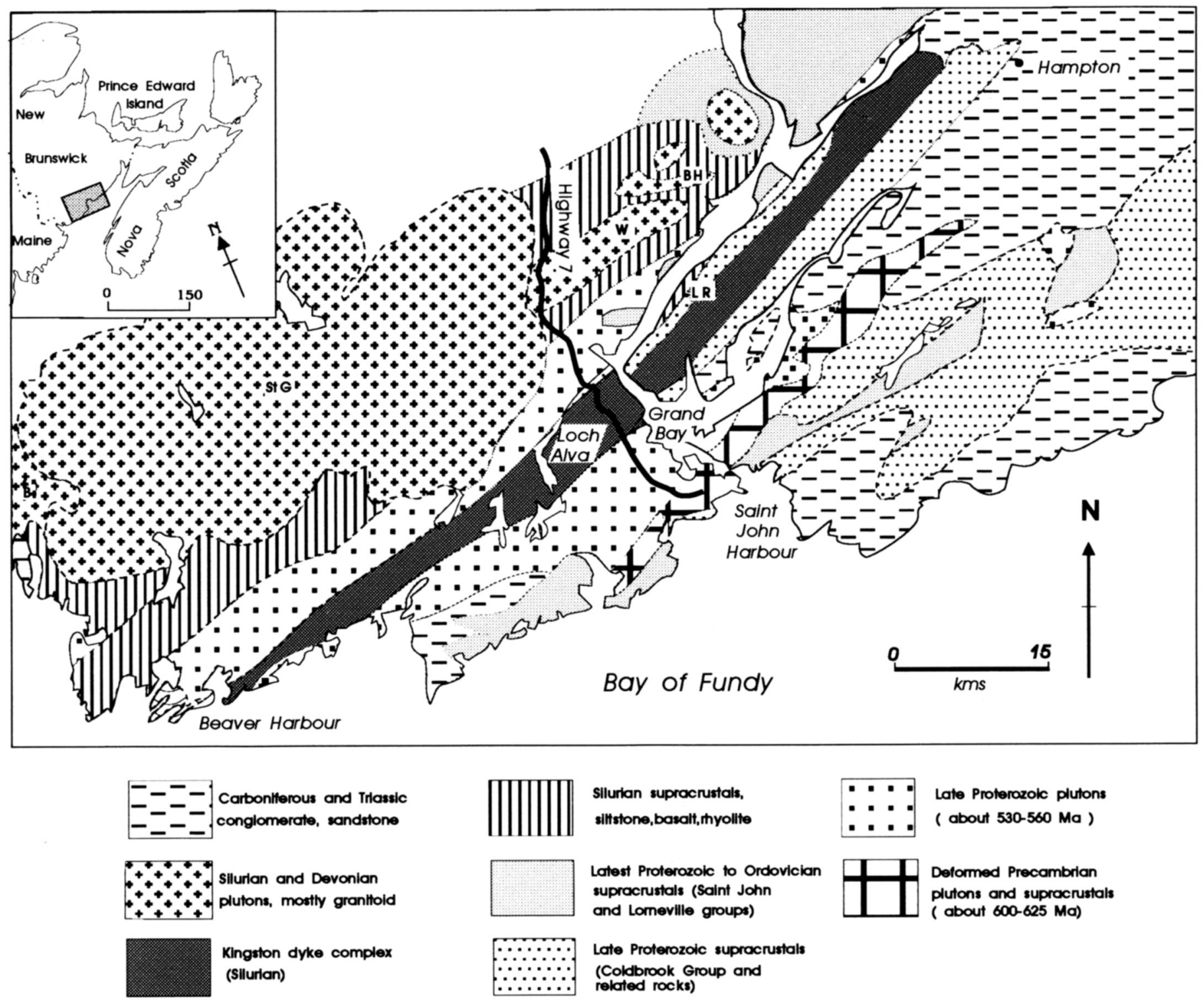

Fig. 1. Geological setting of the Kingston dyke complex. Geological boundaries modified from Currie (1989). St G = St. George batholith, Silurian and Devonian granite plutons; B = Bocabec pluton, Silurian or Devonian gabbro and granite; W = Welsford pluton, Silurian peralkaline granite; $L R=$ Long Reach Formation, Silurian basalt; $B H=$ Silurian Bacon Hill peralkaline rhyolite.

Harbour where the complex is partly covered by late Paleozoic allochthons, to $8 \mathrm{~km}$ along Grand Bay. The complex strikes into the Bay of Fundy southwest of Beaver Harbour and possibly reappears on Campobello Island $40 \mathrm{~km}$ to the southwest (McLeod and Rast, 1988). Northeast of Hampton the complex disappears under Carboniferous cover rocks of the Moncton sub-basin, but a characteristic gravity and magnetic high can be traced on the compilation of Haworth $e t$ al. (1980) for nearly $300 \mathrm{~km}$ from the New Brunswick-Maine boundary to northwestern Prince Edward Island.

The Kingston complex, which consists mainly of steeply dipping dykes, with sub-equal numbers of mafic and salic dykes, has been metamorphosed at upper greenschist facies (possibly to lower amphibolite facies; Nance and Dallmeyer, 1993), but relict igneous features (phenoclasts, flow texture, chilled margins) are commonly preserved. Individual dykes range from 0.4 to $60 \mathrm{~m}$ in width. Due to limited outcrop, no individual dyke has been traced for more than $200 \mathrm{~m}$. The complex as a whole has a uniform trend of $040^{\circ}$, but individual dykes have a more northerly trend, commonly between $015^{\circ}$ and $025^{\circ}$, and along the western side of Grand Bay the dykes trend $150^{\circ}$ to $170^{\circ}$. In addition to dykes, the Kingston complex contains numerous small salic plutons up to $300 \mathrm{~m}$ wide and $1000 \mathrm{~m}$ long. These plutons are invariably elongate parallel to the strike of the dykes, and are likely to be cogenetic with the salic dykes. Plutons appear throughout the complex but are more common southwest of Loch Alva. Screens of host rocks up to $20 \mathrm{~m}$ wide are intercalated with the dykes northeast of Highway 7. These screens are almost entirely composed of intermediate to salic volcanic rocks which petrographically resemble the late Precambrian Coldbrook Group (Currie and Eby, 1990) but are chemically 
distinct. Their source is unknown. A single screen of quartzite was reported by Currie (1984). No screens are known southwest of Highway 7.

The Kingston complex is bounded by faults which cut late Precambrian plutonic and volcanic rocks and Cambrian to lower Ordovician sedimentary rocks. Southwest of Loch Alva the boundaries of the complex are reported to be greenschist-facies mylonitic zones (Rast and Dickson, 1982) up to a kilometre wide which show evidence for late dextral slip (Leger, 1986). Mylonitization is most widespread and intense in adjacent rock units, but mylonitized dykes are common, and a few dykes truncate mylonitic layering at a low angle. East of Loch Alva, the boundaries are brittle fault zones marked by prominent linear magnetic lows. Kinematic analysis of the complex suggests emplacement during sinistral transtension (Currie, 1987) followed by dextral transcurrent movement (Leger, 1986). Both massive and deformed dykes of the Kingston complex were emplaced during the early Silurian (435 Ma, U-Pb zircon, Doig et al., 1990). The age of dextral deformation and metamorphism is distinctly younger (late Silurian to early Devonian), according to $\mathrm{Ar}^{40} / \mathrm{Ar}^{39}$ dating of amphibole (416-390 Ma, Nance and Dallmeyer, 1993).

The Kingston complex lies within late Proterozoic to early Ordovician rocks, the complex stratigraphy and structure of which remain unresolved after more than 150 years of research (see Currie, 1984, 1989 for reviews). Dykes of the complex have not been demonstrated to cut these rocks. [Cross-cutting dykes assigned by Currie (1987) and Dickson (1985) to the Kingston complex are interpreted to belong to older swarms.] However, rocks of the Cambro-Ordovician Saint John Group, and rocks of the underlying "Lorneville beds" (Currie, 1992), occur on both sides of the complex, and tectonic slivers of these rocks are found within the bounding fault zones. The southwestern part of the complex cuts across plutonic rocks, mainly granite and granodiorite. Plutons on both sides of the complex have been dated at about $550 \mathrm{Ma}$ (Currie and Hunt, 1991; Dallmeyer and Nance, 1990), and continuations of some truncated plutons have been tentatively identified on opposite sides of the Kingston complex (Currie, 1987) without significant displacement. It therefore appears unlikely that the Kingston complex marks a major terrane boundary, although it clearly lies within a major transcurrent fault system.

The Kingston complex marks the southeastern boundary of Siluro-Devonian igneous activity in New Brunswick. To the northwest, plutonic and volcanic rocks of these ages are common, ranging from Llandoverian mafic volcanics (Long Reach Formation, Berry and Boucot, 1970) and Pridolian rhyolite (Bacon Hill volcanics, Payette and Martin, 1987) through Silurian alkali granite (Welsford and Jake Lee Mountain plutons, Payette and Martin 1987; Currie, 1987), to Silurian and Devonian plutons of the St. George batholith (McLeod, 1990). All of these units trend northeast, parallel to the Kingston complex.

\section{Description of Lithologies}

The Kingston complex consists of three components: mafic dykes, felsitic dykes, and granophyric to granitic dykes and minor intrusions. Although these rocks have been metamorphosed to upper greenschist or lower amphibolite facies, in many cases relict igneous textures are so well preserved that it is convenient to use igneous terminology.

Mafic dykes consist mainly of plagioclase and amphibole, with varying, but minor, amounts of sphene, chlorite, epidote, quartz and opaque minerals. Textures vary from equigranular and coarse-grained (metagabbro), through ophitic or feldspar-porphyritic with phenocrysts clumped together, to strongly foliated amphibolites. Plagioclase commonly forms relict phenocrysts, varying from aligned laths to large equant tablets. Typically the plagioclase is brownish and cloudy with rims of clear (metamorphic) albite, but the degree of alteration is highly variable. Amphibole in a few cases appears to be secondary after tabular pyroxene, but more commonly it forms ragged prismatic grains with no obvious igneous precursor. Pleochroism is patchy, varying from blue-green through olive shades, commonly with bluegreen rims. $\mathrm{Z}^{\wedge} \mathrm{C}$ is consistently $<^{\circ} 5^{\circ}$, and electron microprobe analyses show $\mathrm{Al}_{2} \mathrm{O}_{3}$ contents $<6 \%$ (Currie, unpublished data) indicating that the amphibole is actinolite, not hornblende. Sphene and epidote form local clumps of secondary grains commonly intergrown with minor quartz. Chlorite, where present, appears to be late and retrograde.

Salic dykes contain relict feldspar phenocrysts, now cloudy and albitic, although many exhibit relict Carlsbad and Baveno twins and may originally have been sanidine. The phenocrysts, which are variably recrystallized to a finegrained mosaic, are set in a fine-grained matrix of quartz and feldspar which varies from mylonitic paste to a trachytoid aggregate, probably a relict of primary igneous texture. Veinlets of epidote and quartz are common. Some mylonitic dykes contain small actinolite or chlorite porphyroblasts along foliation planes. Small aggregates of epidote grains are common. Fine-grained illite occurs around some feldspar phenoclasts.

Granitic dykes contain abundant square relict feldspar phenocrysts, commonly showing relicts of Carlsbad and Baveno twins, but consisting entirely of albite. The original $\mathrm{K}$-rich nature of some of these relicts is evident from relict perthitic texture. Epidote occurs in large mosaic porphyroblasts. Interstitial granophric intergrowth is abundant, readily recognizable even where it has been partially recrystallized.

The metamorphic grade of the dykes is indicated by the ubiquitous actinolite-albite assemblage indicative of greenschist facies. A slightly higher grade assemblage (hornblende-oligoclase) has been reported from the southwestern part of the complex (Nance and Dallmeyer, 1993). It is possible that deeper levels may be exposed from northeast to southwest, as indicated by the increase in number of plutons and amphibolitic dykes, and disappearence of supracrustal 
screens in this direction. The complex has been affected by a mild late retrogression, presumably associated with late faulting, during which chlorite and minor carbonate formed on shear planes.

Examination of continuous sections across the complex in road-cuts along New Brunswick Highway 7 show a fairly strict alternation of salic and mafic dykes. Two adjacent mafic dykes were observed less than once per ten mafic dykes, whereas two adjacent salic dykes are even rarer, probably less than once per hundred salic dykes. The overall abundance of mafic and salic lithologies is sub-equal and slightly weighted to the mafic side. Measurement of three sections totalling $1300 \mathrm{~m}$ suggests about 55 to $60 \%$ mafic dykes. However, individual exposures give more variable results. Some sections of up to $1 \mathrm{~km}$ across strike consist of $75 \%$ mafic dykes, whereas a few sections up to $200 \mathrm{~m}$ in length contain more than $50 \%$ salic dykes (Currie, 1987).

Dyke contacts commonly exhibit mutual chilling, still obvious despite the metamorphic overprint. Mafic dykes exhibit progressive fining of grain size toward the margin, and a sharp, planar contact against neighboring dykes. Salic dykes exhibit loss of phenocrysts toward the margins. Less commonly, a dyke may clearly intrude its neighbor, either as apophyses or cutting across the dyke at a low angle. Salic cutting maffic, and vice versa, occur with about equal frequency. Inclusions of one dyke in another are rare, and we saw no evidence of magma mixing. Sheared contacts, marked by chloritic, locally slickensided surfaces, occur on less than $10 \%$ of dykes in the highway section. These surfaces rarely, if ever, clearly truncate a dyke. Similar sheared contacts surround the screens of host rocks in the complex.

\section{Sample Selection and Analytical Methods}

Twenty-four samples, located and described in the Appendix, were collected for chemical analysis from two road cuts along New Brunswick Highway 7. These road cuts total approximately $800 \mathrm{~m}$ of continuous exposure, or about 150 dykes. Samples represent the various lithologies exposed in these road cuts. The rocks are closely fractured and individual specimen sizes were constrained by the spacing of the fractures, but averaged about $1 \mathrm{~kg}$. Each specimen was slabbed and the fresh interior portion selected for analysis. Powders were prepared by first reducing the size of the fragments using a jaw crusher and a pulverizer with ceramic plates. The resulting fine-grained material was split, and an approximately $\mathbf{2 0}$ gram fraction was reduced to a fine powder in a ceramic mortar and pestle.

Major element chemistry was determined by atomic absorption and emission spectroscopy following the acid dissolution method of Bernas (1968). $\mathrm{Fe}^{2+}$ was determined by titration following the method of Wilson (1955). Precision and accuracy for major elements is estimated to be on the order of $3 \%$. The trace elements $\mathrm{V}, \mathrm{Cr}, \mathrm{Ni}, \mathrm{Cu}, \mathrm{Zn}, \mathrm{Rb}, \mathrm{Sr}, \mathrm{Ba}$, $\mathrm{Y}, \mathrm{Nb}, \mathrm{Pb}, \mathrm{Zr}$ and $\mathrm{Ga}$ were determined by $\mathrm{X}$-ray fluorescence analysis using $10 \mathrm{gram}$ pressed powders. Well-characterized international rock standards were used to construct the working curves. Mass absorption corrections were based on the method of Reynolds (1967). Multiple replicate analyses of USGS standard rocks indicate precision and accuracy for these elements generally on the order of $2 \%$. The trace elements Sc, Co, Cs, La, Ce, Nd, Sm, Eu, Gd, Tb, Tm, Yb, Lu, $\mathrm{Hf}, \mathrm{Ta}$, Th and $\mathrm{U}$ were determined by Instrumental Neutron Activation Analysis (INAA). Samples were irradiated for six hours at a flux of $4 \times 10^{12} \mathrm{n} / \mathrm{cm}^{2}$ and were counted, following suitable decay periods, on a dual-detector fully-automated INAA system. Peak location and integration was performed using Canberra Spectran-AT software and further data reduction was carried out using software developed in-house. Estimated precision and accuracy for these determinations is better than 5\% for all elements except Cs and Gd. The results of these analyses are reported in Table 1.

\section{GeOChemistry}

As is evident from field evidence and Table 1, the Kingston suite is bimodal. The rocks can be divided into two suites, basaltic and rhyolitic-granitic. On most conventional chemical plots, the basalts plot in the tholeiite field. $\mathrm{MgO}$ and $\mathrm{TiO}_{2}$ decrease and $\mathrm{Na}_{2} \mathrm{O}$ increases with increasing $\mathrm{SiO}_{2}$ (Fig. 2). $\mathrm{K}_{2} \mathrm{O}$ is quite variable and generally decreases with increasing $\mathrm{SiO}_{2}$ (Fig. 2). The rhyolites and, in particular, the granites, have very low $\mathrm{K}_{2} \mathrm{O}$ contents. $\mathrm{K}$ and Cs also co-vary with Rb content (Fig. 3), but none of the other geochemically mobile elements (such as $\mathrm{U}$ and $\mathrm{Na}$ ) show a close correspondence with K. We have previously (Currie and Eby, 1990) ascribed this depletion in $\mathrm{K}, \mathrm{Rb}$ and $\mathrm{Cs}$ to a post-magmatic metasomatic event which affected the volcanic rocks of the Saint John area. Given the $\mathbf{4 3 5} \mathrm{Ma}$ date for the Kingston complex, this event is constrained to be younger than $435 \mathrm{Ma}$ and may correspond to the ca. 416 to $390 \mathrm{Ma}$ regional metamorphism reported by Nance and Dallmeyer (1993).

Despite the fact that $\mathrm{Na}_{2} \mathrm{O}$ does not seem to have behaved as a mobile element, we believe the low LIL element content of the salic rocks is not a primary igneous feature. Although $\mathrm{Na}_{2} \mathrm{O}$ generally increases with increasing $\mathrm{SiO}_{2}, \mathrm{~K}_{2} \mathrm{O}$ is quite variable and tends to decrease with increasing $\mathrm{SiO}_{2}$ (Fig. 2). $\mathrm{K}_{2} \mathrm{O}$ is high in some of the silica-rich dykes, whereas other dykes show extreme depletion (Fig. 2). These observations are not readily explained by igneous processes. Badger (1993) has investigated element mobility during greenschist facies metamorphism of Late Proterozoic basalts of the Catoctin volcanic province; $\mathrm{K}_{2} \mathrm{O}, \mathrm{Na}_{2} \mathrm{O}, \mathrm{Rb}, \mathrm{Ba}$ and $\mathrm{Sr}$ were found to be the most easily mobilized elements. The degree of mobilization was related to the intensity of alteration, and both relative enrichment and depletion in the mobile elements was noted. In more intense alteration zones, concentrations of $\mathrm{SiO}_{2}, \mathrm{CaO}, \mathrm{MgO}$ and $\mathrm{FeO}$ were also found to vary. In the Kingston complex the large-ion-lithophile (LIL) elements were clearly mobile and to Badger's list of mobile elements we would add Cs. The granitic dykes are significantly depleted in $\mathrm{K}\left(\mathrm{K}_{2} \mathrm{O}<0.14 \%\right)$ and $\mathrm{Cs}$. It is quite possible that the extreme depletion of these elements in the granitic dykes was due to the coarser grain size which allowed easy access for the metasomatic fluids. 
Table 1. Analytical data for Kingston dykes.

\begin{tabular}{|c|c|c|c|c|c|c|c|c|c|c|c|c|c|}
\hline $\begin{array}{l}\text { Sample } \\
\text { Unit }^{1}\end{array}$ & $\begin{array}{c}\text { NB50 } \\
\text { M2 }\end{array}$ & $\begin{array}{c}\text { NB52 } \\
\text { M1 }\end{array}$ & $\begin{array}{c}\text { NB53 } \\
\text { M1 }\end{array}$ & $\begin{array}{c}\text { NB55 } \\
\text { M3 }\end{array}$ & $\begin{array}{c}\text { NB58 } \\
\text { M3 }\end{array}$ & $\begin{array}{c}\text { NB59 } \\
\text { M2 }\end{array}$ & $\begin{array}{c}\text { NB60 } \\
\text { M2 }\end{array}$ & $\begin{array}{c}\text { NB61 } \\
\text { M2 }\end{array}$ & $\begin{array}{c}\text { NB62 } \\
\text { M2 }\end{array}$ & $\begin{array}{c}\text { NB64 } \\
\text { M2 }\end{array}$ & $\begin{array}{c}\text { NB67 } \\
\text { M3 }\end{array}$ & $\begin{array}{c}\text { NB69 } \\
\text { M2 }\end{array}$ & $\begin{array}{c}\text { NB71 } \\
\text { M2 }\end{array}$ \\
\hline Nt. \% & 12 & 84 & 140 & 08 & 26 & 18 & 865 & 287 & 8 & 7 & 19 & & 0 \\
\hline $\begin{array}{l}\mathrm{SIO}_{2} \\
\mathrm{TiO}_{2}\end{array}$ & $\begin{array}{r}1.12 \\
2.08\end{array}$ & $\begin{array}{l}48.04 \\
1.64\end{array}$ & $\begin{array}{r}44.93 \\
1.94\end{array}$ & $\begin{array}{r}49.81 \\
2.49\end{array}$ & $\begin{array}{r}49.60 \\
0.85\end{array}$ & $\begin{array}{r}34.81 \\
1.41\end{array}$ & $\begin{array}{r}4.05 \\
2.08\end{array}$ & $\begin{array}{r}40.01 \\
1.75\end{array}$ & $\begin{array}{r}J 0.10 \\
1.99\end{array}$ & $\begin{array}{l}J .07 \\
1.07\end{array}$ & $\begin{array}{r}40.00 \\
1.67\end{array}$ & $\begin{array}{r}5.0 J \\
0.78\end{array}$ & $\begin{array}{l}7.05 \\
1.32\end{array}$ \\
\hline $\mathrm{Al}_{2} \mathrm{O}_{3}$ & 14.83 & 15.81 & 14.95 & 13.98 & 18.30 & 14.47 & 14.20 & 15.33 & 15.31 & 16.18 & 15.04 & 16.47 & 17.84 \\
\hline $\mathrm{Fe}_{2} \mathrm{O}_{3}$ & 3.38 & 2.44 & 2.00 & 3.48 & 1.88 & 1.70 & 3.53 & 2.23 & 4.83 & 2.54 & 4.30 & 2.33 & 1.73 \\
\hline $\mathrm{FeO}$ & 9.64 & 9.07 & 9.96 & 11.38 & 6.93 & 8.45 & 10.01 & 10.3 & 8.09 & 7.60 & 10.57 & 6.95 & 8.36 \\
\hline $\mathrm{MnO}$ & 0.31 & 0.20 & 0.27 & 0.37 & 0.17 & 0.21 & 0.31 & 0.27 & 0.18 & 0.24 & 0.25 & 0.24 & 0.21 \\
\hline $\mathrm{MgO}$ & 5.11 & 8.55 & 8.29 & 5.57 & 4.69 & 5.20 & 6.73 & 6.99 & 5.79 & 6.83 & 7.30 & 5.77 & 5.57 \\
\hline $\mathrm{CaO}$ & 6.76 & 9.17 & 8.00 & 8.01 & 7.89 & 5.51 & 9.07 & 9.84 & 9.15 & 8.46 & 5.93 & 8.06 & 10.33 \\
\hline $\mathrm{Na}_{2} \mathrm{O}$ & 3.13 & 2.21 & 2.07 & 3.75 & 3.54 & 4.49 & 2.74 & 3.09 & 3.82 & 4.07 & 3.39 & 4.61 & 2.80 \\
\hline $\mathrm{K}_{2} \mathrm{O}$ & 0.83 & 1.37 & 1.53 & 0.46 & 1.53 & 0.57 & 1.42 & 0.34 & 0.58 & 0.12 & 1.32 & 0.16 & 1.06 \\
\hline $\begin{array}{l}\text { Total } \\
\text { ppm }\end{array}$ & 97.19 & 98.50 & 93.94 & 99.30 & 95.38 & 96.82 & 98.74 & 99.01 & 99.92 & 98.68 & 95.85 & 99.22 & 98.87 \\
\hline Sc & 36.3 & 34.1 & 33.8 & 40.1 & 23.3 & 33.7 & 42.8 & 42.4 & 36.8 & 33.0 & 38.0 & 28.7 & 35.1 \\
\hline V & 305 & 206 & 228 & 316 & 142 & 184 & 277 & 254 & 292 & 182 & 246 & 166 & 198 \\
\hline $\mathrm{Cr}$ & 69 & 241 & 201 & 94 & 184 & 113 & 152 & 184 & 68 & 144 & 130 & 122 & 134 \\
\hline Co & 66 & 49 & 48 & 38 & 27 & 31 & 41 & 44 & 32 & 34 & 26 & 25 & 34 \\
\hline $\mathrm{Ni}$ & 19 & 133 & 130 & 42 & 73 & 26 & 42 & 52 & 36 & 65 & 77 & 55 & 45 \\
\hline $\mathrm{Cu}$ & 85 & 66 & 47 & 48 & 53 & 122 & 43 & 77 & 212 & 48 & 227 & 14 & 46 \\
\hline $\mathrm{Zn}$ & 193 & 127 & 164 & 165 & 122 & 141 & 245 & 181 & 65 & 94 & 115 & 81 & 69 \\
\hline $\mathbf{R b}$ & 34.4 & 56.8 & 57.7 & 15.1 & 55.1 & 18.3 & 47.0 & 14.1 & 25.2 & 6.1 & 46.4 & 6.7 & 43.5 \\
\hline Cs & n.d. & n.d. & n.d. & n.d. & 1.11 & n.d. & n.d. & n.d. & 0.5 & 0.3 & n.d. & n.d. & 0.9 \\
\hline $\mathrm{Sr}$ & 271 & 229 & 191 & 187 & 433 & 251 & 258 & 284 & 510 & 299 & 218 & 353 & 240 \\
\hline $\mathrm{Ba}$ & 169 & 197 & 416 & 116 & 410 & 175 & 192 & 82 & 164 & 59 & 258 & 72 & 182 \\
\hline $\mathrm{La}$ & 19.9 & 8.7 & 9.2 & 11.4 & 14.5 & 16.6 & 10.5 & 8.2 & 22.6 & 10.4 & 8.0 & 12.1 & 7.9 \\
\hline$\overline{\mathrm{Ce}}$ & 48.4 & 18.7 & 21.5 & 31.8 & 30.7 & 39.7 & 28.9 & 22.6 & 60.3 & 24.5 & 21.4 & 30.2 & 22.2 \\
\hline $\mathbf{N d}$ & 27.6 & 15.5 & 16.8 & 20.8 & 18.3 & 21.2 & 19.9 & 16.1 & 34.1 & 14.2 & 14.8 & 15.7 & 16.4 \\
\hline $\mathrm{Sm}$ & 6.86 & 4.11 & 4.87 & 5.74 & 4.16 & 4.82 & 5.29 & 4.44 & 7.41 & 3.80 & 4.69 & 3.74 & 4.49 \\
\hline $\mathrm{Eu}$ & 2.13 & 1.51 & 1.74 & 1.92 & 1.27 & 1.45 & 1.89 & 1.49 & 2.18 & 1.30 & 1.67 & 1.18 & 1.41 \\
\hline Gd & 6.5 & 5.0 & 5.7 & 7.2 & 4.2 & 5.1 & 6.4 & 5.2 & 7.9 & 4.7 & 5.3 & 4.1 & 5.0 \\
\hline $\mathrm{Tb}$ & 1.13 & 0.78 & 0.88 & 1.14 & 0.72 & 0.89 & 0.99 & 0.90 & 1.16 & 0.73 & 0.93 & 0.66 & 0.86 \\
\hline $\mathrm{Tm}$ & 0.63 & 0.42 & 0.51 & 0.51 & 0.31 & 0.4 & 0.58 & 0.41 & 0.51 & 0.37 & 0.54 & 0.38 & 0.49 \\
\hline $\mathrm{Yb}$ & 4.01 & 2.75 & 3.42 & 3.90 & 2.01 & 2.96 & 3.50 & 2.95 & 3.30 & 2.35 & 3.44 & 2.30 & 3.14 \\
\hline $\mathrm{Lu}$ & 0.63 & 0.45 & 0.52 & 0.62 & 0.33 & 0.49 & 0.55 & 0.49 & 0.56 & 0.38 & 0.55 & 0.37 & 0.49 \\
\hline$Y$ & 40.1 & 29.2 & 34.7 & 43.0 & 21.8 & 33.8 & 36.2 & 33.2 & 38.4 & 25.2 & 36.4 & 24.7 & 34.2 \\
\hline $\mathrm{Nb}$ & 8.7 & 5.9 & 5.5 & 8.3 & 4.9 & 7.8 & 6.8 & 6.7 & 6.2 & 6.4 & 5.2 & 6.3 & 6.1 \\
\hline $\mathrm{Pb}$ & 22.0 & 6.1 & 5.5 & 17.9 & 14.7 & 9.0 & 6.9 & 27.9 & 7.1 & 7.2 & 1.8 & 7.2 & 5.5 \\
\hline$Z_{r}$ & 173 & 106 & 119 & 163 & 101 & 145 & 134 & 116 & 145 & 108 & 143 & 103 & 131 \\
\hline Hf & 4.4 & 2.4 & 2.9 & 4.2 & 2.6 & 3.7 & 3.4 & 2.9 & 3.9 & 2.9 & 3.5 & 2.8 & 3.4 \\
\hline Ta & 0.59 & 0.30 & 0.27 & 0.55 & 0.26 & 0.61 & 0.32 & 0.32 & 0.33 & 0.36 & 0.27 & 0.41 & 0.31 \\
\hline Th & 3.9 & n.d. & 0.88 & 1.81 & 2.68 & 6.77 & 0.96 & 0.92 & 3.24 & 3.00 & 0.70 & 4.33 & 1.35 \\
\hline $\mathbf{U}$ & 0.77 & n.d. & n.d. & 0.77 & 0.58 & 2.32 & n.d. & n.d. & 0.85 & 0.77 & n.d. & 0.94 & 0.32 \\
\hline $\mathrm{Ga}$ & 21.4 & 17.9 & 18.3 & 21.6 & 16.2 & 16.4 & 18.6 & 19.2 & 20.4 & 17.7 & 20.1 & 18.3 & 19.6 \\
\hline
\end{tabular}

${ }^{1} \mathrm{M} 1$ = fine-grained mafic dyke, $\mathrm{M} 2$ = medium-grained mafic dyke, low Ni trend, $\mathrm{M} 3$ = medium-grained mafic dyke, high Ni trend, $R=$ rhyolitic dyke, $\mathbf{G}=$ granitic dyke. n.d. $=$ not detected.

\section{Mafic dykes}

The mafic dyke compositions are projected onto pseudoliquidus ternary diagrams (Fig. 4) using the procedure of Sack et al. (1987). This projection implicitly includes the oxidation state of $\mathrm{Fe}$, and we have set $\mathrm{Fe}^{2+}=85 \%$ of the total $\mathrm{Fe}$. Assuming that the fugacity of the basaltic magmas was not far removed from that of the QFM buffer, this is a reasonable value based on equation (9) in Sack et al. (1980). On the Olivine-Diopside-Silica ternary diagram (Fig. 4a) 
Table 1. Continued.

\begin{tabular}{|c|c|c|c|c|c|c|c|c|c|c|c|}
\hline $\begin{array}{l}\text { Sample } \\
\text { Unit }^{1}\end{array}$ & $\begin{array}{c}\text { NB49 } \\
\text { R }\end{array}$ & $\begin{array}{c}\text { NB51 } \\
\text { R }\end{array}$ & $\begin{array}{c}\text { NB54 } \\
\text { R }\end{array}$ & $\begin{array}{c}\text { NB56 } \\
\text { R }\end{array}$ & $\begin{array}{c}\text { NB57 } \\
\text { R }\end{array}$ & $\begin{array}{c}\text { NB65 } \\
\text { R }\end{array}$ & $\begin{array}{c}\text { NB70 } \\
\text { R }\end{array}$ & $\begin{array}{c}\text { NB63 } \\
\text { G }\end{array}$ & $\begin{array}{c}\text { NB66 } \\
\text { G }\end{array}$ & $\begin{array}{c}\text { NB68 } \\
\text { G }\end{array}$ & $\begin{array}{c}\text { NB72 } \\
\text { G }\end{array}$ \\
\hline \multicolumn{12}{|l|}{ wt.\% } \\
\hline $\mathrm{SiO}_{2}$ & 69.60 & 68.39 & 71.59 & 69.02 & 68.56 & 73.94 & 73.62 & 74.23 & 73.13 & 72.00 & 73.09 \\
\hline $\mathrm{TiO}_{2}$ & 0.46 & 0.26 & 0.33 & 0.34 & 0.34 & 0.31 & 0.18 & 0.21 & 0.20 & 0.18 & 0.19 \\
\hline $\mathrm{Al}_{2} \mathrm{O}_{3}$ & 12.33 & 13.47 & 14.50 & 14.57 & 16.03 & 13.70 & 13.00 & 13.05 & 13.38 & 12.31 & 12.70 \\
\hline $\mathrm{Fe}_{2} \mathrm{O}_{3}$ & 1.49 & 1.53 & 0.82 & 0.98 & 0.57 & 0.99 & 0.77 & 0.81 & 0.71 & 0.53 & 0.96 \\
\hline $\mathrm{FeO}$ & 5.60 & 3.80 & 0.80 & 1.98 & 1.00 & 0.40 & 0.90 & 2.41 & 1.24 & 2.72 & 2.49 \\
\hline $\mathrm{MnO}$ & 0.11 & 0.08 & 0.04 & 0.07 & 0.05 & 0.03 & 0.06 & 0.05 & 0.04 & 0.07 & 0.05 \\
\hline $\mathrm{MgO}$ & 1.28 & 0.67 & 0.57 & 1.06 & 0.93 & 0.39 & 1.02 & 0.39 & 0.71 & 0.69 & 0.34 \\
\hline $\mathrm{CaO}$ & 2.47 & 1.50 & 1.24 & 3.93 & 0.93 & 0.97 & 1.75 & 2.05 & 2.19 & 2.51 & 2.40 \\
\hline $\mathrm{Na}_{2} \mathrm{O}$ & 4.69 & 4.43 & 5.86 & 5.54 & 6.12 & 7.19 & 6.49 & 5.98 & 6.40 & 5.71 & 5.99 \\
\hline $\mathrm{K}_{2} \mathrm{O}$ & 0.48 & 2.94 & 1.31 & 0.20 & 2.40 & 0.04 & 0.08 & 0.04 & 0.08 & 0.13 & 0.08 \\
\hline Total & 98.51 & 97.07 & 97.06 & 97.69 & 96.93 & 97.96 & 97.87 & 99.22 & 98.08 & 96.85 & 98.29 \\
\hline $\begin{array}{l}\text { ppm } \\
\text { Sc }\end{array}$ & 7.2 & 5.2 & 5.0 & 5.7 & 4.7 & 3.1 & 5.2 & 3.5 & 3.4 & 3.4 & 3.5 \\
\hline V & 52.1 & 20.8 & 17.4 & 29.3 & 14.8 & 20.3 & 14.3 & 9.6 & 9.0 & 8.1 & 10.0 \\
\hline $\mathrm{Cr}$ & 96 & 153 & 40.1 & 33.7 & 33.2 & 29.4 & 25.1 & 17.7 & 17.2 & 19.7 & 16.8 \\
\hline Co & 9.1 & 6.8 & 2.9 & 3.1 & 2.4 & 1.73 & 7.3 & 1.1 & 4.3 & 1.74 & 1.53 \\
\hline $\mathrm{Ni}$ & 23.5 & 26.9 & 8.7 & 7.4 & 6.0 & 3.4 & 7.3 & 3.1 & 4.1 & 4.1 & 3.6 \\
\hline $\mathrm{Cu}$ & 37 & 668 & 880 & 53 & 49 & 48 & 32 & 25 & 44 & 29 & 24 \\
\hline $\mathrm{Zn}$ & 73 & 33 & 33 & 55 & 40 & 19 & 24 & 20 & 21 & 24 & 22 \\
\hline $\mathbf{R b}$ & 12.7 & 49 & 21.5 & 4.8 & 21.2 & n.d. & 0.9 & n.d. & 0.8 & 2.3 & 0.9 \\
\hline Cs & n.d. & n.d. & 0.17 & n.d. & 0.35 & n.d. & n.d. & n.d. & n.d. & n.d. & n.d. \\
\hline $\mathrm{Sr}$ & 208 & 169 & 124 & 311 & 181 & 78 & 110 & 112 & 134 & 122 & 114 \\
\hline $\mathrm{Ba}$ & 190 & 1005 & 414 & 84 & 1032 & 42 & 70 & 41 & 53 & 70 & 54 \\
\hline $\mathrm{La}$ & 34.9 & 50.8 & 57.4 & 49.7 & 57.2 & 32.9 & 51.0 & 65.8 & 85.7 & 62.5 & 61.5 \\
\hline $\mathrm{Ce}$ & 61 & 111 & 121 & 107 & 121 & 60 & 105 & 142 & 178 & 137 & 137 \\
\hline Nd & 23.2 & 44.2 & 51.5 & 45.2 & 49.9 & 26.3 & 50.6 & 71.4 & 87.6 & 68.2 & 69.0 \\
\hline Sm & 5.10 & 10.4 & 11.5 & 9.8 & 11.5 & 5.07 & 11.3 & 16.5 & 17.7 & 16.3 & 16.6 \\
\hline $\mathrm{Eu}$ & 1.10 & 1.65 & 1.65 & 1.62 & 1.45 & 0.59 & 1.17 & 2.94 & 3.07 & 2.68 & 2.62 \\
\hline Gd & n.d. & 10.0 & 10.4 & 9.9 & 11.0 & n.d. & 11.3 & 15.7 & 14.8 & 17.0 & 16.5 \\
\hline $\mathrm{Tb}$ & 0.87 & 1.64 & 1.75 & 1.53 & 1.75 & 0.81 & 1.87 & 2.78 & 2.52 & 2.75 & 2.77 \\
\hline $\mathrm{Tm}$ & 0.50 & 1.00 & 1.05 & 1.01 & 1.06 & 0.62 & 1.03 & 1.65 & 1.31 & 1.53 & 1.62 \\
\hline $\mathrm{Yb}$ & 3.06 & 6.31 & 6.79 & 6.43 & 7.15 & 3.90 & 7.67 & 10.37 & 8.54 & 10.90 & 10.69 \\
\hline $\mathrm{Lu}$ & 0.48 & 1.00 & 1.15 & 1.04 & 1.23 & 0.63 & 1.22 & 1.66 & 1.38 & 1.80 & 1.76 \\
\hline$Y$ & 30.6 & 56.9 & 65.1 & 58.4 & 68.8 & 38.6 & 69.0 & 106 & 82.8 & 112 & 110 \\
\hline $\mathrm{Nb}$ & 11.0 & 16.0 & 17.3 & 17.2 & 20.0 & 13.8 & 19.1 & 20.8 & 18.1 & 23.6 & 24.1 \\
\hline $\mathrm{Pb}$ & 9.5 & 13.0 & 7.9 & 10.8 & 10.1 & 5.6 & 5.9 & 5.9 & 6.4 & 7.4 & 7.0 \\
\hline $\mathrm{Zr}$ & 157 & 405 & 459 & 456 & 522 & 302 & 418 & 555 & 444 & 625 & 601 \\
\hline $\mathrm{Hf}$ & 4.74 & 11.5 & 12.7 & 12.3 & 13.4 & 7.76 & 12.6 & 16.1 & 12.2 & 18.3 & 17.2 \\
\hline $\mathrm{Ta}$ & 1.05 & 1.07 & 1.19 & 1.22 & 1.33 & 1.14 & 1.46 & 1.51 & 1.29 & 1.65 & 1.71 \\
\hline Th & 21.8 & 18.1 & 19.6 & 19.5 & 21.2 & 19.4 & 16.3 & 14.4 & 13.0 & 15.8 & 15.8 \\
\hline $\mathrm{U}$ & 4.96 & 3.86 & 4.25 & 4.06 & 4.51 & 4.01 & 3.09 & 3.60 & 2.82 & 4.01 & 4.16 \\
\hline Ga & 13.3 & 12.8 & 16.2 & n.d. & 17.1 & 15.8 & 15.6 & 24.8 & 21.6 & 23.4 & 25.2 \\
\hline
\end{tabular}

most of the samples plot parallel to, but on the olivine side of, the olivine-Ca-pyroxene cotectic. A group of five samples form a trend away from the Olivine corner. When projected onto the Silica-Plagioclase-Olivine diagram (Fig. 4b), the samples cluster around the plagioclase-olivine cotectic and scatter into the plagioclase field. Because of the post-magmatic metasomatism the whole-rock compositions have been modified. This metasomatism seems to have largely affected the distribution of $\mathrm{K}, \mathrm{Rb}$ and $\mathrm{Cs}$ (see discussion above). If $\mathrm{K}$ is added to a sample which plots on the cotectic, it will tend to move into the plagioclase field. Conversely, depletion in $\mathrm{K}$ will tend to move the sample into the olivine field. The absolute magnitude of this affect will not be large, and it seems reasonable to conclude that the close correspondence of most of these samples to the plagioclase-olivine cotectic indicates that the magmas were saturated with these two phases when they were intruded. 

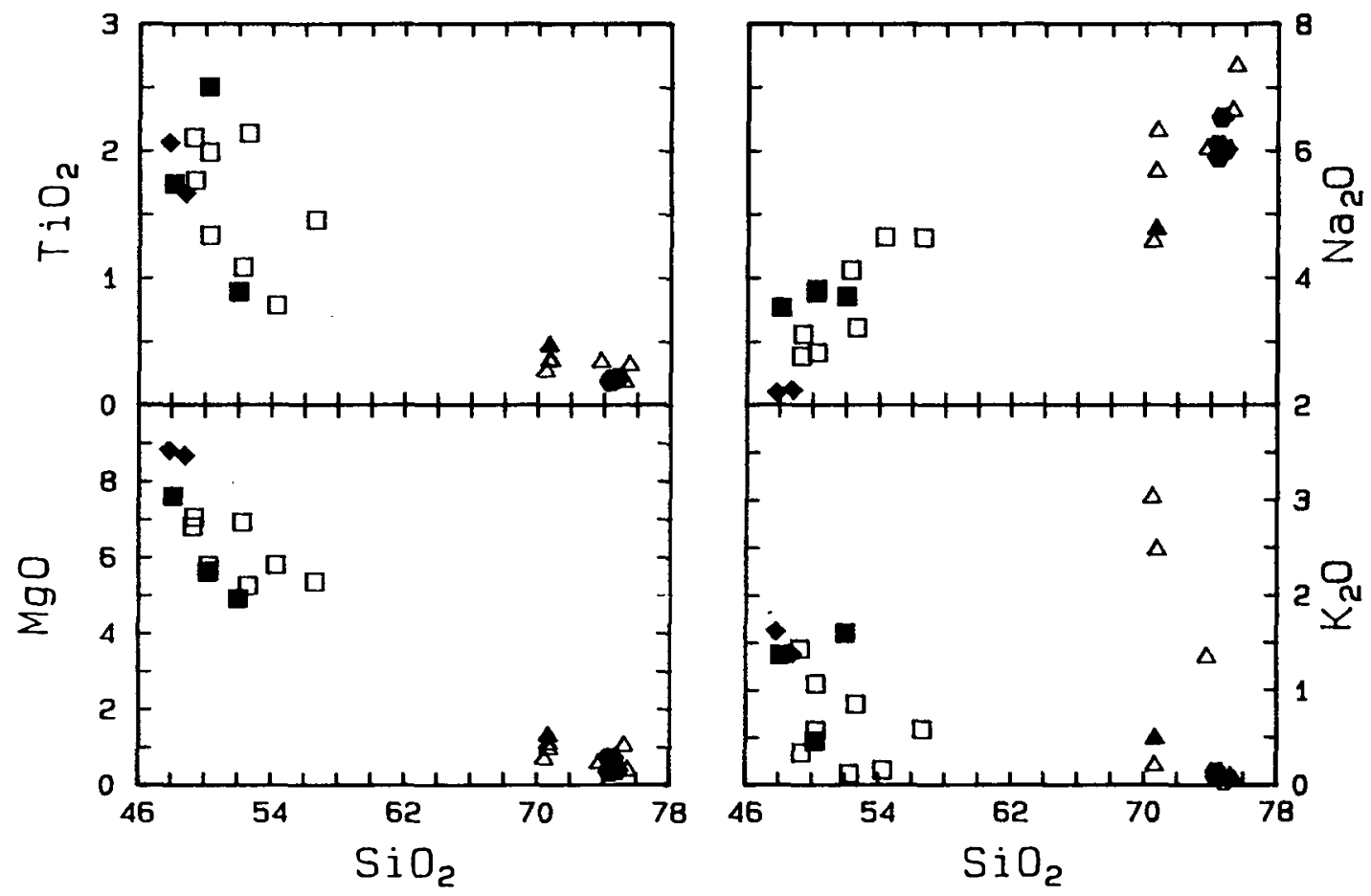

Fig. 2. Major element variations versus $\mathrm{SiO}_{2}$ (wt. \%). A number of mafic and salic dykes contain very low $\mathrm{K}_{2} \mathrm{O}$. Symbol key: filled diamonds = fine-grained mafic dykes; open squares = medium-grained mafic dykes, low Ni trend; filled squares = medium-grained mafic dykes, high Ni trend; open triangles = rhyolitic dykes; filled triangle = rhyolitic dyke with pyroxene clumps; filled hexagons = granitic dykes.

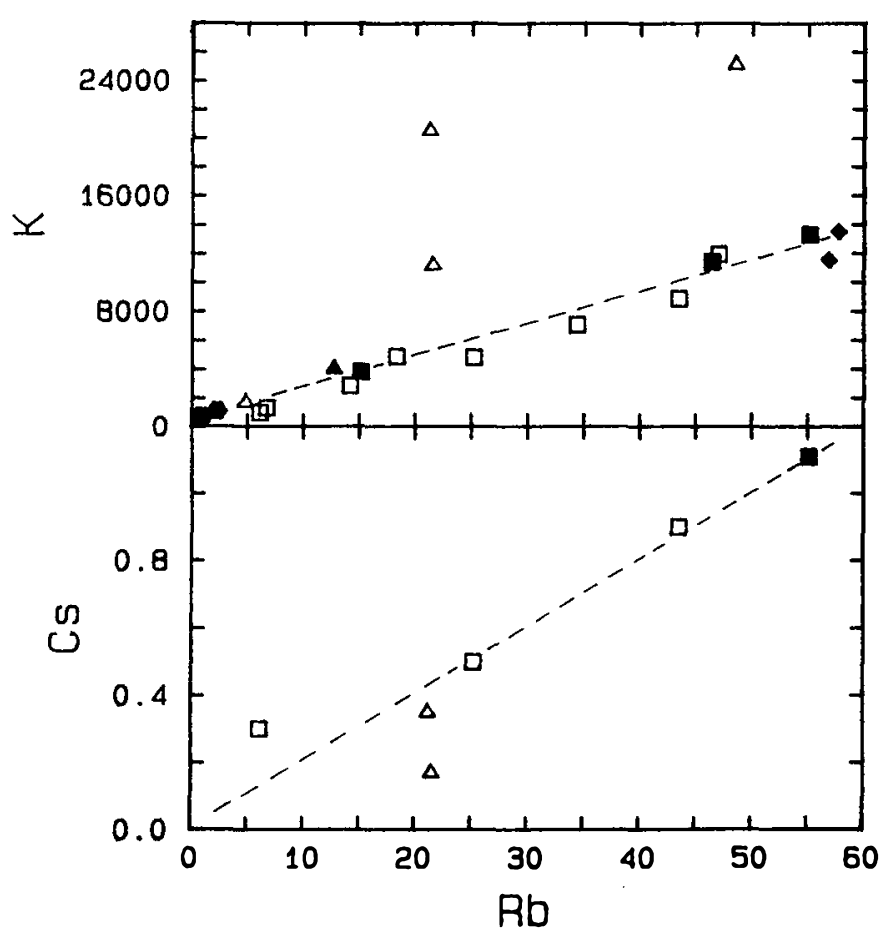

Fig. 3. $\mathrm{K}$ and $\mathrm{Cs}$ concentrations versus $\mathrm{Rb}$ (ppm). The covariation of these elements indicates that they were similarly affected by late-stage metasomatism. Granitic dykes show extreme depletion of $\mathrm{K}$ and $\mathrm{Rb}$. For many of the samples the $\mathrm{Cs}$ abundance was below the INAA detection limit. Same symbols as Figure 2.
In terms of trace element geochemistry, several trends can be noted (Fig. 5). Ni decreases regularly with decreasing

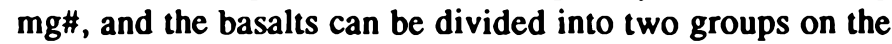
basis of their $\mathrm{Ni}$ content. The samples forming the higher $\mathrm{Ni}$ trend correspond to those which plot as a trend away from the Olivine corner on the Olivine-Ca-pyroxene-Silica psuedoternary diagram (Fig. 4a). These observations support the contention the olivine was a significant phase during the fractionation of the basaltic magmas. Conversely, Sc abundances are quite variable with respect to $\mathrm{mg} \#$, and the lack of a pattern suggests that pyroxene was not involved in the evolution of the magmas. $V$ tends to increase with decreasing $m g \#$ (although there is scatter), which suggests that magnetite was not fractionated from the magmas. The Eu/Eu* ratio versus $\mathrm{mg \#}$ is quite variable (Fig. 5), but a number of the samples do fall along a plagioclase fractionation trend. Phenocrysts are rare in the basaltic dykes, but where found are exclusively plagioclase. Thus the textural and chemical evidence indicate that the basaltic magmas were saturated with respect to plagioclase and olivine.

\section{Salic dykes}

In general, there has been extensive alteration of the salic dykes, as indicated by their very low $\mathrm{K}, \mathrm{Rb}$ and $\mathrm{Cs}$ contents (Figs. 2,3). Given this extensive alteration, it is likely that the concentrations of a number of the other LIL elements have also been affected by metasomatism. Thus a number of elements that might be used to map magmatic evolution are 

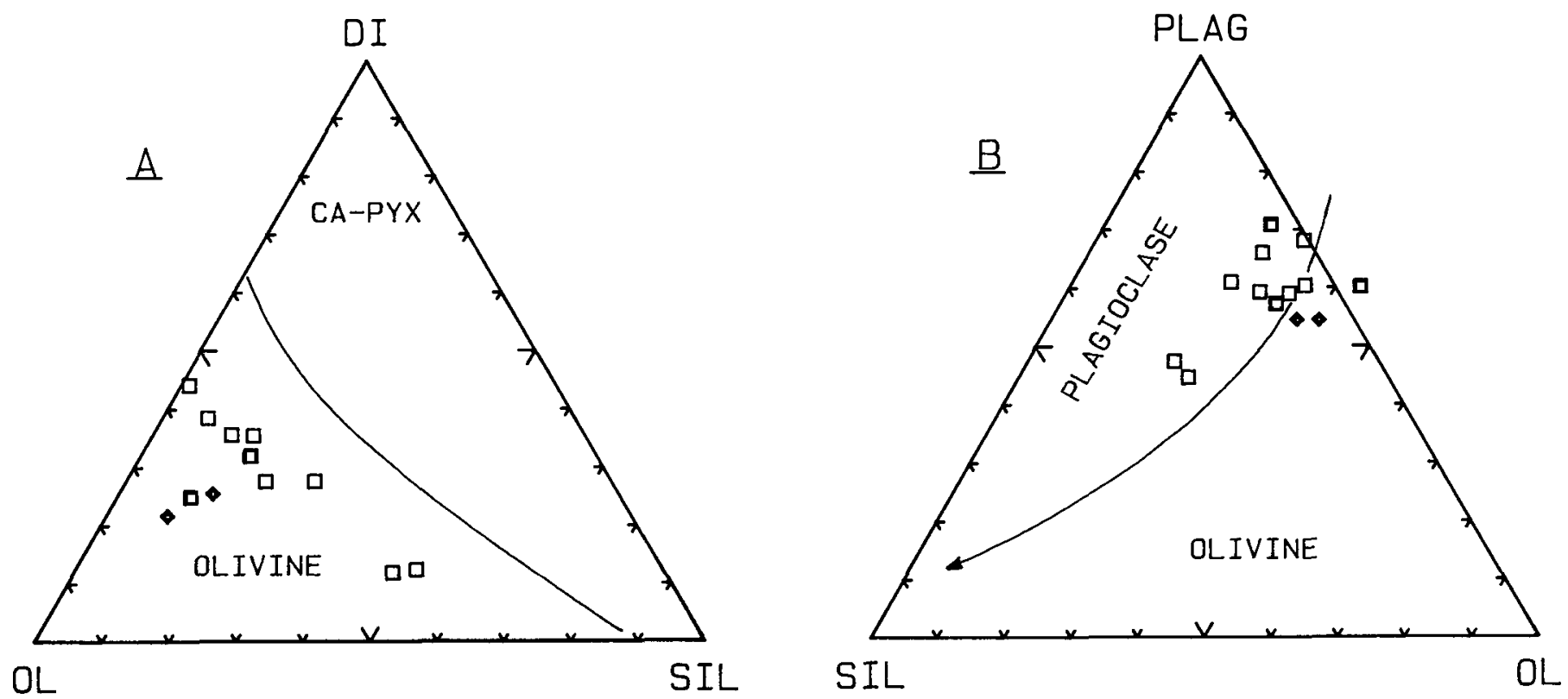

Fig. 4. Compositions of Kingston mafic dykes projected onto pseudoliquidus ternary diagrams using the projection scheme of Sack et al. (1987). (A) Olivine-Diopside-Pyroxene projection. The dykes that form the high-Ni trend plot on a line away from the olivine corner. The other samples form a trend parallel to, but offset from, the $1 \mathrm{~atm}$. olivine-Ca-pyroxene cotectic (Sack et al. 1987). (B) SilicaPlagioclase-Olivine projection. The dykes cluster around the 1 atm. plagioclase-olivine cotectic (from Stolper, 1980), indicating that plagioclase and olivine were crystallizing from these magmas. Same symbols as Figure 2.
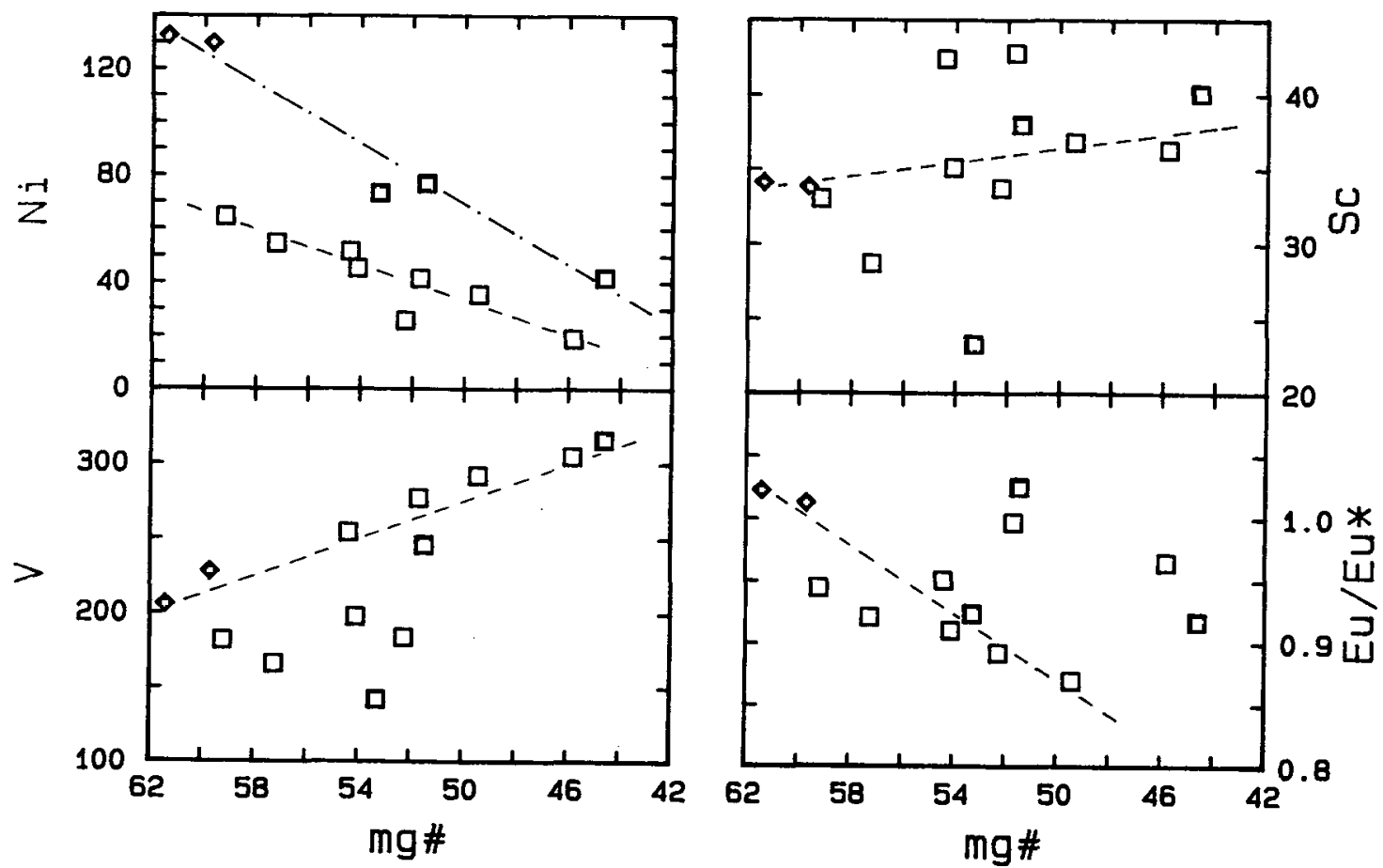

Fig. 5. Plot of concentration (ppm) of $\mathrm{Ni}, \mathrm{V}$ and $\mathrm{Sc}$ and the $\mathrm{Eu} / \mathrm{Eu}^{*}$ ratio versus $\mathrm{mg} \#$ (calculated by setting $\mathrm{Fe}_{2} \mathrm{O}_{3}=0.15 \mathrm{Fe} \mathrm{i}_{\text {tous }}$ ) for the mafic dykes. Two separate trends can be distinguished based on the Ni content of the dykes. Dashed lines are fractionation trends for Ni, V, Sc and Eu/Eu*. Same symbols as Figure 2.

not reliable indicators for this suite of dykes. For this reason we have restricted our analysis to the HCD cations which should be relatively immobile during low to medium grade metamorphism.
As an indicator of magmatic evolution, we have selected the HCD cation $\mathrm{Nb}$. $\mathrm{Nb}$ abundances in the salic dykes are strongly positively correlated with $\mathrm{Zr}, \mathrm{Ta}, \mathrm{Y}$ and $\mathrm{Yb}$. Thus any of these elements would suffice as an indicator. Although 
relict phenocrysts are relatively rare in the rhyolitic dykes, where found they are pyroxene and plagioclase. Variations in Sc abundances and the $\mathrm{Eu} / \mathrm{Eu}^{*}$ ratios of the rhyolitic and granitic dykes can be explained largely by fractionation of variable amounts of feldspar and pyroxene (Fig. 6). The essentially constant Sc concentration of the granitic dykes indicates that pyroxene fractionation was much less important in the evolution of this suite of rocks. Th and Nb co-vary in the granitic dykes, but not in the rhyolitic dykes (Fig. 6). This observation can be interpreted to indicate that the granitic dykes evolved by closed system fractionation of a single magma whereas the rhyolitic dykes either represent open system crystallization or multiple sources. In a general way the $(\mathrm{Ce} / \mathrm{Yb})_{\mathrm{N}}$ ratio decreases with increasing $\mathrm{Nb}$ (Fig. 6). Feldspar fractionation can cause a declining $(\mathrm{Ce} / \mathrm{Yb})_{\mathrm{N}}$ ratio. Given the mineralogical and chemical evidence it seems reasonable to conclude that evolution of the salic dykes was largely controlled by fractionation of feldspar and pyroxene, with variable degrees of open system crystallization.

\section{Discussion}

Elemental variations for the mafic and salic dykes, relative to N-MORB, are shown on Figure 7. The spidergram for the basaltic dykes is very similar to that of the Coldbrook basalts (Currie and Eby, 1990) with the exception of Cs, which is not relatively depleted in the Kingston dykes. The salic dyke spidergram illustrates the extreme depletion of $\mathrm{K}$ in the granitic dykes, the relative depletion of both $C s$ and $R \mathbf{b}$ in most dykes, the depletion in $\mathrm{Ba}$ and $\mathrm{Sr}$ which can be ascribed to fractional crystallization of feldspar, and the strong depletion in Ti. U, which is commonly a mobile element, seems not to have been affected by post-emplacement metasomatism as it plots with Th on the spidergram trends. Compared to the mafic dykes, Ta is enriched with respect to $\mathrm{Nb}$ in the felsic dykes.

Th and $\mathrm{Ga}$ abundances and $\mathrm{Yb} / \mathrm{Ta}$ and $(\mathrm{Ce} / \mathrm{Yb})_{\mathrm{N}}$ ratios for the entire dyke suite are plotted versus $\mathrm{SiO}_{2}$ on Figure 8. Of particular note is the decline in the $\mathrm{Yb} / \mathrm{Ta}$ ratio with increasing $\mathrm{SiO}_{2}$ shown by the mafic dykes. None of the inferred fractionating phases would have a significant effect on the $\mathrm{Yb} / \mathrm{Ta}$ ratio. This trend can be explained as a mixing line involving a relatively high $\mathrm{SiO}_{2}$ - low $\mathrm{Yb} / \mathrm{Ta}$ component. A possible candidate would be material similar to average crust which has a $\mathrm{Yb} / \mathrm{Ta}$ ratio of about 2 (Taylor and McLennan, 1985). A similar argument can explain the variation in the $(\mathrm{Ce} / \mathrm{Yb})_{\mathrm{N}}$ ratio that also greatly exceeds the one expected to be produced by fractional crystallization alone. In this case, our contaminant end member would have a $(\mathrm{Ce} / \mathrm{Yb})_{n}$ ratio on the order of 4 to 5 . Since we do not have a chemical analysis of this possible end member, or isotopic data, quantitative modelling of such a mixing process is not possible. However, the data are suggestive of an open system process involving both fractional crystallization and crustal assimilation.

The spidergrams suggest that there are significant differences between the mafic and salic dykes of the Kingston
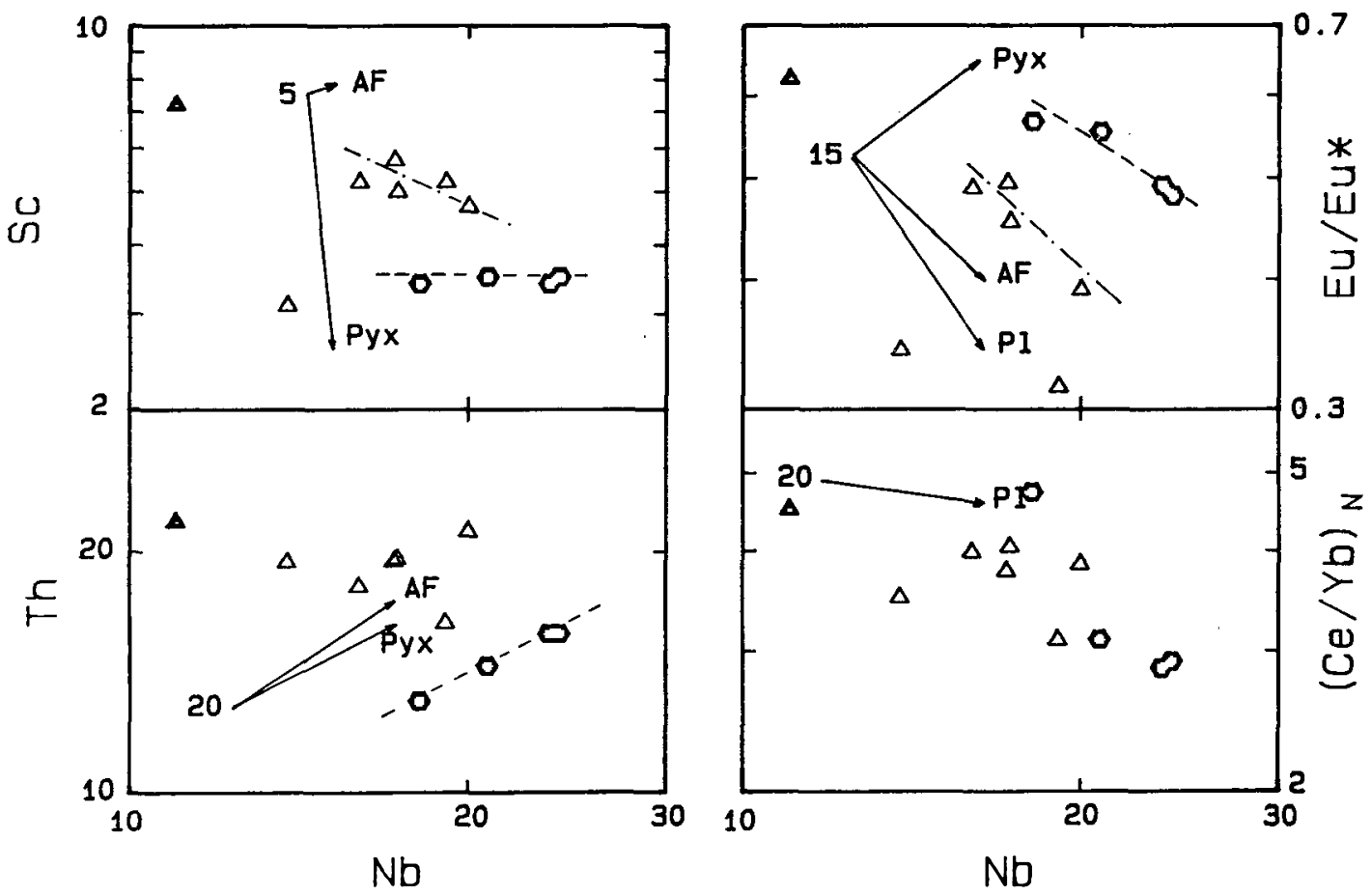

Fig. 6. Sc and Th abundances (ppm) and $\mathrm{Eu} / \mathrm{Eu}^{*}$ and $(\mathrm{Ce} / \mathrm{Yb})_{\mathrm{N}}$ ratios for the salic dykes versus $\mathrm{Nb}$ (ppm). The expected effects of alkali feldspar (AF), plagioclase (Pl) and pyroxene (Pyx) fractional crystallization are shown as vectors on the diagrams. The number at the origin of each vector cluster represents the percent fractional crystallization. The vectors were calculated by assuming that $\mathrm{Nb}$ is a perfectly incompatible element. Partition coefficients used to calculate the variations in the other elemental abundances are from Henderson (1982). See text for discussion. Same symbols as Figure 2. 


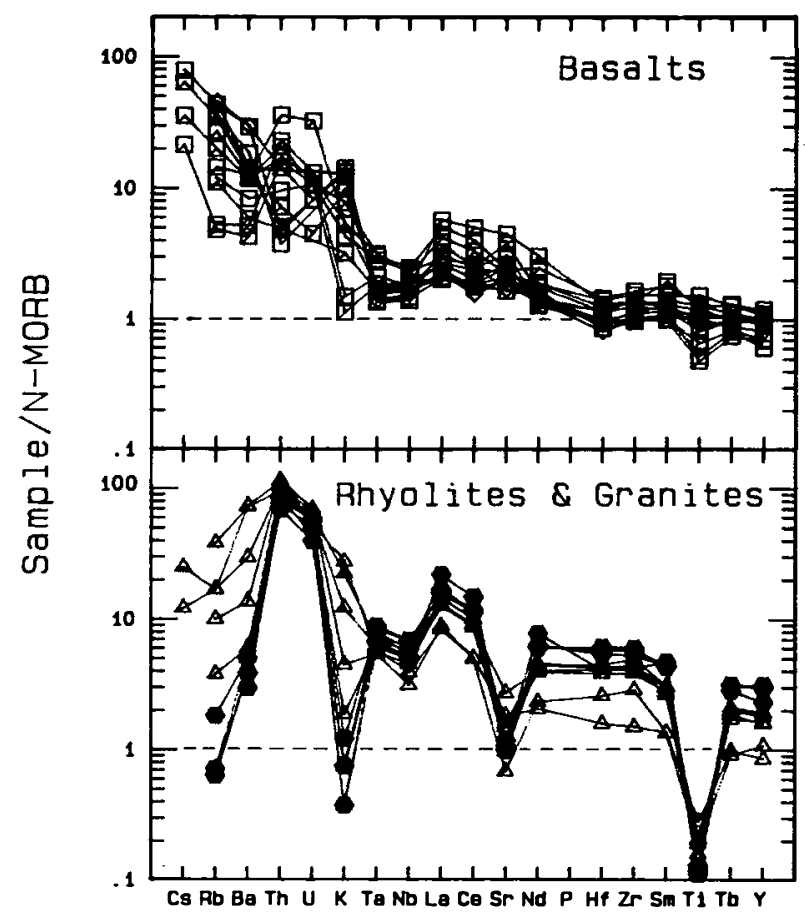

Fig. 7. Spidergram for Kingston mafic and salic dykes. Elemental abundances normalized to N-MORB (Hofmann, 1988). Same symbols as Figure 2.

complex. Thus the question arises as to the relationship between the mafic and salic dykes. The granitic dykes generally show distinct geochemical differences with respect to the rhyolitic dykes (Fig. 8), suggesting different sources. The most notable of these differences is the higher $\mathrm{Ga}$ content of the granitic dykes. On several of the plots in Figure 8 the rhyolitic dykes plot in areas which might represent extensions of the mafic dyke trend. Ayuso and Bevier (1991) have reported $\mathrm{Pb}$ isotopic ratios for feldspar from one of the rhyolitic dykes, and the $\mathrm{Pb}$ isotopic data permit a Precambrian component in this dyke (Bevier, personal communication, 1992). We suggest that the rhyolitic dykes were derived by partial melting of Precambrian rocks at depth and that this same material served as the contaminant for the mafic dykes. The granitic dykes have a different, unidentified source, chemically similar to some of the granites of the St. George batholith (see discussion below).

The chemistry of the Kingston mafic dykes is compared to that of the Coldbrook and other basalts of the Saint John region in Figure 9. The Kingston basalts show the same continental margin and island arc basalt signature as the older Coldbrook Group and Lorneville beds. Dostal and McCutcheon (1990) similarly found continental margin signatures for basalts from the Kingston complex. In contrast, on the basis of major element chemistry, Dickson (1985) concluded that dykes west of Loch Alva are tholeiites of continental rift affinity. However, we believe that the major element chemistry and limited suite of trace elements analysed in this work were unsuitable for confident discrimination of basalt affinities.
Emplacement of dyke suites requires a transtensional or tensional environment. The continental margin signature is therefore anomalous and unlikely to reflect the tectonic setting during emplacement of the Kingston complex. All basalts emplaced in the Saint John district between the late Precambrian and the Silurian carry the same trace element signature (Eby and Currie, in preparation), which must represent the source material of the magmas. The most probable source is a late Precambrian underplate emplaced during a continental-margin subduction episode (Currie and Eby, 1990) and repeatedly tapped by subsequent reheating. Since total melting during such reheating is improbable, the underplate must have included substantial amounts of "fertile" lithospheric mantle.

Chemical data for the salic dykes of the Kingston complex are plotted on granitoid discrimination diagrams of Pearce et al. (1984) and Whalen et al. (1987) (Fig. 10). The dykes show within plate and A-type granitoid characteristics. According to the classification of A-type granites recently proposed by Eby (1992), the Kingston salic dykes belong to the $A_{2}$ group. Granitoids which characterize this group have been emplaced in post-collisional - post-subduction settings during periods of extension, exactly analogous to the apparent setting of the Kingston complex. Also plotted on these diagrams are fields showing the range of compositions observed for the various suites from the slightly younger A-type granitoids of the St. George batholith (McLeod, 1990; Whalen, 1993). There is significant overlap between chemistries of the St. George suites and granitic dykes of the Kingston complex and to a lesser extent some overlap with the rhyolitic dykes. We interpret this to indicate that felsic rocks of the Kingston complex were generated from sources similar to those which produced the St. George batholith.

\section{Emplacement Mechanism and Tectonic Significance}

A crude estimate of the rate of emplacement of the Kingston complex can be obtained from the observation that the complex consists almost entirely of dykes which did not significantly interact with each other and still exhibit relicts of chilled margins. The host rocks of each dyke (that is, earlier dykes) therefore remained cool and rigid relative to the injected magma. Data on high temperature creep summarised by Cruden (1990) suggest that this rigidity requires that temperature in the host rocks was below roughly $600^{\circ} \mathrm{C}$. We assume that the emplacement rate was such that the complex widened at $\mathrm{v} \mathrm{m} / \mathrm{sec}$. The amount of heat added per unit area per unit time is $v^{*}\left(\mathrm{Cv}^{*}\left(\mathrm{~T}_{1}-\mathrm{T}_{\mathrm{s}}\right)+\mathrm{L}\right)$, where $\mathrm{C}_{\mathrm{v}}$ is the heat capacity of the magma per unit volume, $T_{1}$ the temperature of the magma, $T_{s}$ the temperature of the host, and $L$ the heat of melting per unit volume of the magma. The heat loss is $-\mathbf{k}$ grad $T$ where $k$ is the thermal conductivity. We assume constant $T_{s}=400^{\circ}$ and heat loss in the vertical direction only. Balance of heat fluxes requires that

$$
v=\left(-k^{*} d T / d z\right) /\left(C_{v}{ }^{*}\left(T_{1}-400\right)+L\right)
$$



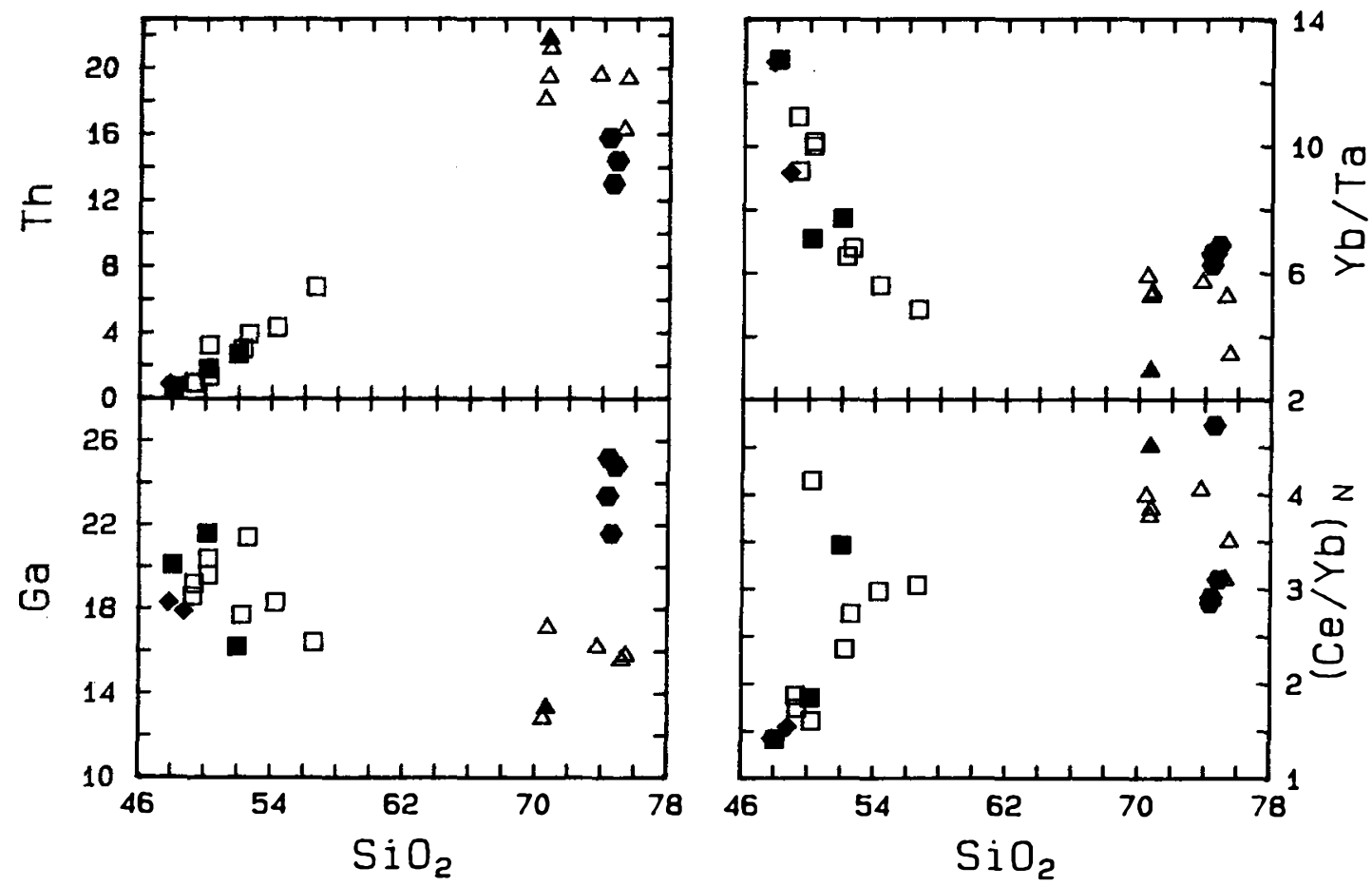

Fig. 8. Plot of $\mathrm{Th}$ and $\mathrm{Ga}(\mathrm{ppm})$ and $\mathrm{Yb} / \mathrm{Ta}$ and $(\mathrm{Ce} / \mathrm{Yb})_{\mathrm{N}}$ ratios versus $\mathrm{SiO}_{2}$ (wt. \%) for the Kingston dykes. Same symbols as Figure 2 . The rhyolitic dykes tend to plot in regions that could represent end member compositions for a crustal component which mixed with the mafic magmas.
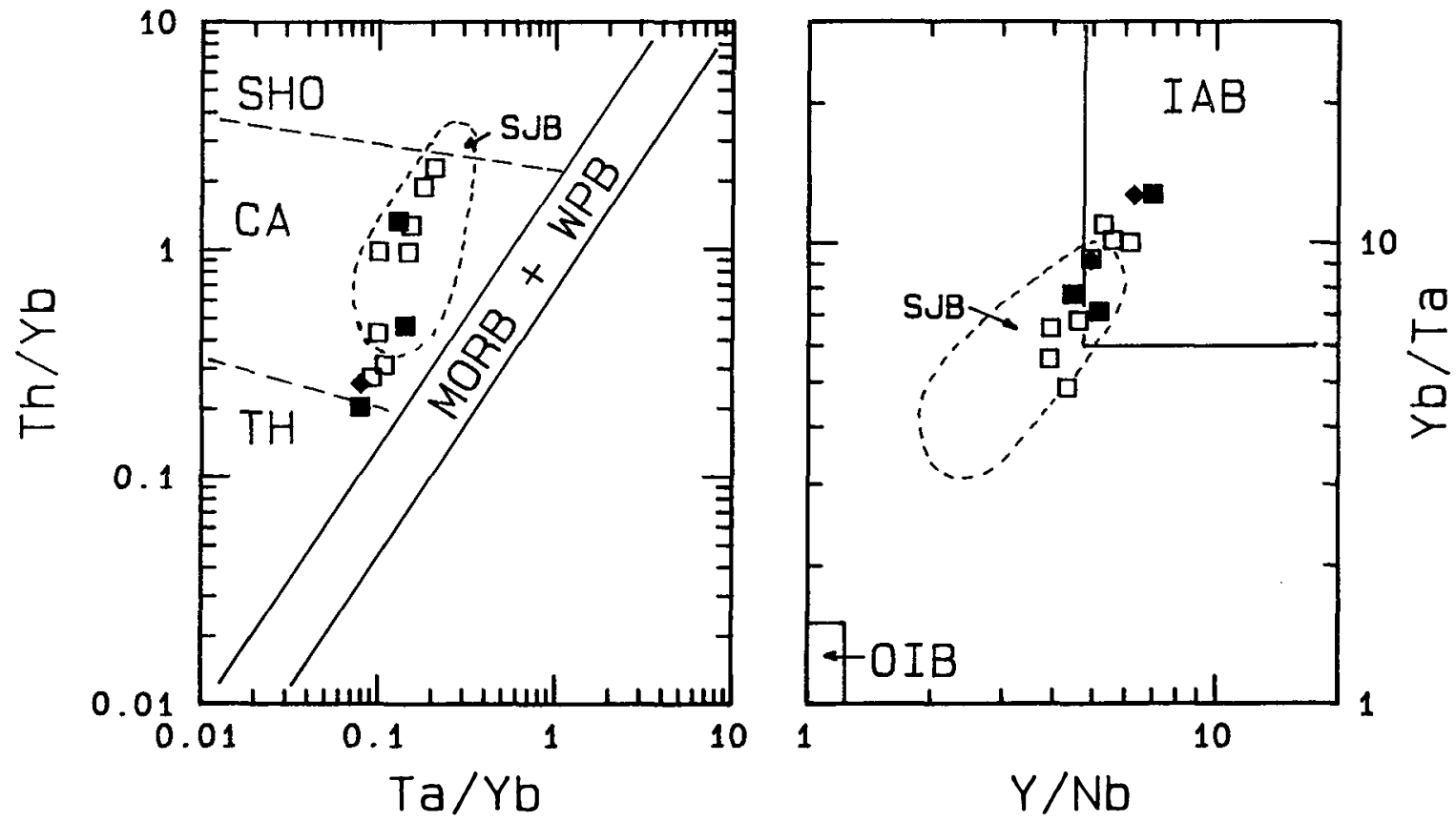

Fig. 9. Ta/Yb vs. Th/Yb diagram of Pearce (1983) and Y/Nb vs. Yb/Ta diagram of Eby (1990). Despite the extensional setting of the Kingston complex, the Kingston mafic dykes plot in the continental margin basalt and island arc basalt fields on both diagrams, and there is almost complete overlap with the other basalts of the Saint John district (SJB). Same symbols as Figure 2.

Reasonable values of $\mathrm{k}=2.75 \mathrm{~W} /(\mathrm{mK}), \mathrm{C}_{\mathrm{v}}=2.78 * 10^{6} \mathrm{~J} /\left(\mathrm{m}^{3} \mathrm{~K}\right)$, $\mathrm{L}=4.19 * 10^{8} \mathrm{~J} / \mathrm{m}^{3}$ (deBremaecker, 1985 ), $\mathrm{T}_{1}=1000^{\circ} \mathrm{C}$ and $\mathrm{dT} /$ $\mathrm{dz}=80^{\circ} / \mathrm{km}$, give $\mathrm{v}=1.05^{*} 10^{-10} \mathrm{~m} / \mathrm{sec}$ or $3.33 \mathrm{~km} / \mathrm{million}$ years. To emplace the Kingston complex, which is locally more than $8 \mathrm{~km}$ wide, would therefore require 2 to 3 million years. A higher value for $T_{s}$ would increase this value. Contemporaneous salic and mafic dykes demonstrate that both types of magma must have been present throughout this period. The 

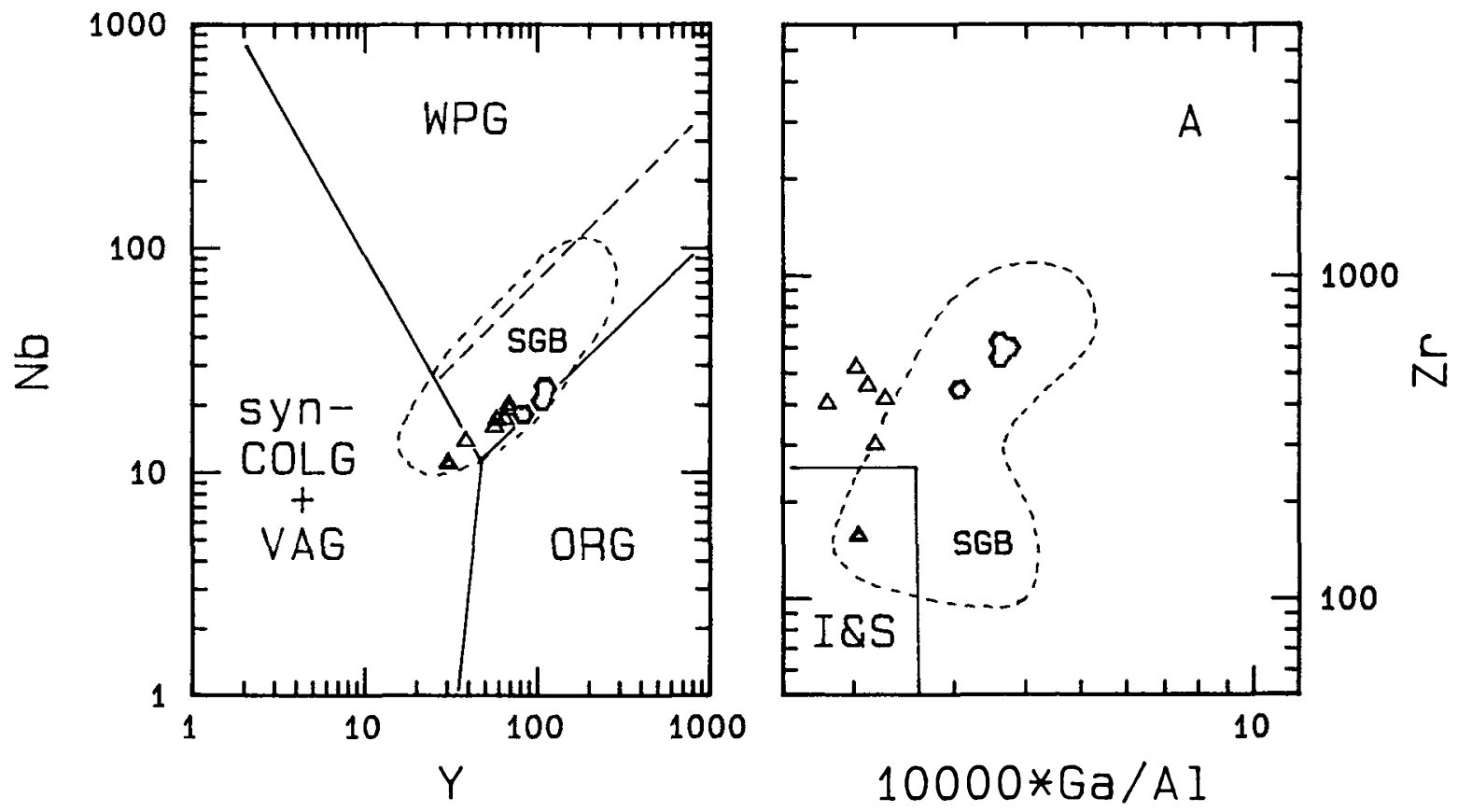

Fig. 10. Plots of Kingston salic dykes on granite discrimination diagrams. On the Y-Nb tectonic discriminant diagram of Pearce et al. (1984), the salic dykes fall in the WPG field. On the $\mathrm{Zr}-10000 * \mathrm{Ga} / \mathrm{Al}$ of Whalen et al. (1987) the salic dykes fall in the A-type granite field. The dashed field represents granitoid rocks of the St. George batholith (SGB). Data for St. George batholith from McLeod (1990) and Whalen (1993). Same symbols as Figure 2.

experiments of Huppert and Sparks (1988) suggested that the presence of more than 5 to $10 \%$ liquid leads to buoyant instability and the rise of blob-like masses of magma, rather than thin dykes. Thus both the mafic and salic sources must have been mostly solid, although presumably close to the melting temperature. A small amount of mafic liquid, insufficient to rise buoyantly without mechanical assistance, could be tapped by a fault. As it passed through the salic layer, the mafic magma would add heat to it, setting off an episode of melting. In this model a mafic dyke and accompanying salic dyke form a thermally connected pair, which will tend to follow the same central, heated path along the fault plane. The scale of intrusion is limited by plastic relaxation of the source region which will seal the fault. Each mafic-salic pair therefore represents an increment of motion on the fault. Mixing of the salic and mafic portions is inhibited by the relatively rapid passage of the mafic liquid, by the planar geometry which is unfavorable for convective mixing, and by slow thermal equilibration, so that the salic liquid is mobilized only after mafic liquid has passed.

For such a system to operate, both mafic and salic sources must be maintained at temperatures near the melting point, that is, at temperatures above $1200^{\circ} \mathrm{C}$ in the upper mantle for the mafic dykes, and above $800^{\circ} \mathrm{C}$ at the base of the crust for the salic dykes. Such a system is not in thermal equilibrium. Equilibration results in major heat transfer to the crust and hence to the creation of large volumes of magma. Our model of dyke emplacement must therefore be terminated by slightly younger major plutonism, which would normally engulf and metamorphose an older dyke suite. The
Kingston complex was not engulfed, although it was metamorphosed, because emplacement of the St. George batholith, commencing at about $432 \mathrm{Ma}$ (compared to the emplacement age of $435 \mathrm{Ma}$ for the Kingston complex) and continuing intermittently for $70 \mathrm{Ma}$ (McLeod, 1990), was offset a few kilometers to the northwest. We assume that this offset resulted from fault movements along the southern edge of the Fredericton basin (McKerrow and Ziegler, 1971) so that the Kingston complex was removed from the thermal anomaly.

The deduced juxtaposition of (relatively) cool crust above hot upper mantle along a deep fault could only result from a major tectonic dislocation. Van Staal (1987) advanced evidence that late Ordovician-early Silurian crustal delamination brought hot mantle close to the base of the continental crust over much of the northern Appalachians, initiating major Silurian plutonism and deformation. At about the same time fault motions reversed from sinistral to dextral (Currie and Piasecki, 1988). Present outcrop of Silurian plutons and metamorphic rocks stops abruptly along major deep faults (Dover-Hermitage system in Newfoundland, Stockmal et al., 1987; Wheaton Brook fault in New Brunswick, van Staal and Fyffe, 1991), but belts of mixed late Precambrian and Silurian plutonic rocks in southwestern Newfoundland (Dunning and O'Brien, 1989), northwestern Cape Breton Island (Barr and Raeside, 1986) and New England (Hatch et al., 1984) lie northwest of the boundary faults, and fragments of late Precambrian plutons outcrop far to the west (Evans et al., 1990; Roddick and Bevier, 1988). The southeastern boundary of Silurian plutons and metamorphism therefore does not exactly coincide with the northwestern boundary of the late 
Precambrian Avalon zone. The Kingston complex illustrates how a planar Silurian thermal anomaly could impinge on cool Avalonian crust. All components of the Kingston complex, including mafic dykes, were derived from Avalonian lithosphere. Despite melting at deep crustal levels, late Precambrian rocks southeast and northwest of the Kingston complex were little affected by thermal metamorphism (Dallmeyer and Nance, 1990). This preservation appears to result from removal of the rocks from the heat source before thermal equilibrium could be reached. In the (more usual?) case where Avalonian lithosphere remained in contact with the heat source we assume thermal equilibration would lead to large-scale melting and metamorphism, producing terranes dominated by Silurian plutons and strongly metamorphosed mixed Silurian-Precambrian assemblages, such as those observed in southwestern Newfoundland and northwestern Cape Breton Island. A mechanical boundary between hot, easily deformed rocks to the northwest and cold, strong rocks to the southeast (such as the Dover-Hermitage and correlative faults) could only migrate if the cold, strong rocks are broken and softened, for example, by the impingement of a thermal anomaly along faults. The Kingston complex represents a possible example of this process frozen at an early stage.

\section{Acknowledgements}

INAA data were obtained using the facilities of the University of Massachusetts, Lowell, Radiation Laboratory. The XRF analyses were conducted at Oxford and Mr. Keith Parish (Oxford) assisted in the acquisition of the XRF trace element data. We are indebted to Damian Nance and Steve McCutcheon for constructive reviews which improved the manuscript, and to Damian Nance for supplying an important reference prior to publication.

Ayuso, R.A. and Bevier, M.L. 1991. Regional differences in $\mathrm{Pb}$ isotopic compositions of feldspars in plutonic rocks of the northern Appalachian Mountains, U.S.A. and Canada: A geochemical method of terrane correlation. Tectonics, 10 , pp. 191-212.

BADGER, R.L. 1993. Fluid interaction and geochemical mobility in metabasalts: An example from the central Appalachians. Journal of Geology, 101, pp. 85-95.

BarR, S.M. and Raeside, R.P. 1986. Pre-Carboniferous tectonostratigraphic subdivision of Cape Breton Island. Maritime Sediments and Atlantic Geology, 22, pp. 252-263.

Bernas, B. 1968. A new method for decomposition and comprehensive analysis of silicates by atomic absorption spectrometry. Analytical Chemistry, 40, pp. 1682-1686.

Berry, W.B.N. and Boucot, A.J. 1970. Correlation of the North American Silurian rocks. Geological Society of America, Special Paper 102, 289 p.

Cruden, A.R. 1990. Flow and fabric development during the diapiric rise of magma. Journal of Geology, 98, pp. 681-698.

Cumming, C.L. 1916 The igneous rocks of Saint John, New Brunswick. Unpublished Ph.D thesis, Princeton University, Princeton, New Jersey.
CURRIE, K.L. 1984. A reconsideration of some geological relations near Saint John, New Brunswick. In Current Research, Part A, Geological Survey of Canada, Paper 84-1A, pp. 193201.

1987. Precambrian igneous activity in the Musquash-Loch Alva region, southern New Brunswick. In Current Research, Part A, Geological Survey of Canada, Paper 87-1A, pp. 663671.

1989. The western end of the Avalon zone in southern New Brunswick. Atlantic Geology, 24, pp. 339-352.

_ 1992. The "Lomeville beds": a latest Precambrian sequence near Saint John, New Brunswick. In Current Research, Part A, Geological Survey of Canada, Paper 92-1D, pp. 663-671.

CURRIE, K.L. and EBY, G.N. 1990. Geology and geochemistry of the late Precambrian Coldbrook Group near Saint John, New Brunswick. Canadian Journal of Earth Sciences, 27, pp. 1418-1430.

Currie, K.L. and Hunt, P.A. 1991. Latest Precambrian igneous activity near Saint John, New Brunswick. Geological Survey of Canada, Paper 90-2, pp. 11-17.

Currie, K.L. and Piasecki, M.A.J. 1989. Kinematic model for southwestern Newfoundland based upon Silurian sinistral shearing. Geology, 17, pp. 938-941.

DALLMEYER, R.D. and NANCE, R.D. $1990 .{ }^{40} \mathrm{Ar} /{ }^{39} \mathrm{Ar}$ ages of detrital muscovite within early Paleozoic overstep sequences, Avalon composite terrane, southem New Brunswick; implications for extent of the late Paleozoic thermal overprint. Canadian Journal of Earth Sciences, 27, pp. 1209-1214.

DeBremaecker, J.-C. 1985. Geophysics: The Earths Interior. John Wiley and Sons, New York, 342 p.

Dickson, L.W. 1985. Geology, geochemistry and petrology of the Precambrian and Carboniferous rocks between Saint John and Beaver Harbour, southern New Brunswick. Unpublished Ph.D. thesis, University of New Brunswick, Fredericton, New Brunswick, 294 p.

Doio, R., Nance, R.D., Murphy, J.B., and Casseday, R.P. 1990. Evidence for Silurian sinistral accretion of Avalon composite terrane in Canada. Journal of the Geological Society of London, 147, pp. 927-930.

Dostal, J. and McCutcheon, S.R. 1990. Geochemistry of Late Proterozoic basaltic rocks from southeastern New Brunswick, Canada. Precambrian Research, 47, pp. 83-98.

Dunning, G.R. and O'Brien, S.J. 1989. Late Proterozoic-early Paleozoic crust in the Hermitage flexure, Newfoundland Appalachians: $\mathrm{U} / \mathrm{Pb}$ ages and tectonic significance. Geology, 17, pp. 548-551.

Eв Y, G.N. 1990. The A-type granitoids: a review of their occurrence and chemical characteristics and speculations on their petrogenesis. Lithos, 26, pp. 115-134.

1992. Chemical subdivision of the A-type granitoids: Petrogenetic and tectonic implications. Geology, 20, pp. 641644.

Evans, D.T.W., Kean, B.F., and Dunning, G.R. 1990. Geological studies, Victoria Lake Group, central Newfoundland. Newfoundland Geological Surveys, Branch Report 90-1, pp. 131-144.

Hatch, N.L., Zen, E-AN, Goldsmith, R., Ratcliff, N.M., RobinSON, P., Stanley, R.S., and Wones, D.R. 1984. Lithologic assemblages as portrayed on the new bedrock map of Massachusetts. American Joumal of Science, 284, pp. 1026-1034.

Ha worth, R.T., Daniels, D.L., Williams, H., and Zietz, I. 
1980. Bouguer gravity anomaly map of the Appalachian orogen. Memorial University of Newfoundland, Map No. 3.

Helmstaedt, H. 1968. Structural and metamorphic analysis in Beaver Harbour region, Charlotte County, New Brunswick. Unpublished Ph.D. thesis, University of New Brunswick. Fredericton, New Brunswick, 213 p.

Henderson, P. 1982. Inorganic Geochemistry. Pergamon Press Limited, Oxford, 353 p.

HormanN, A.W. 1988. Chemical differentiation of the earth: the relationship between mantle, continental crust, and oceanic crust. Earth and Planetary Science Letters, 90, pp. 297-314.

Huppert, H.E. and Sparks, R.S.J. 1988. The fluid dynamics of crustal melting by injection of basaltic sills. Transactions of the Royal Society of Edinburgh-Earth Sciences, 79, pp. 237 244.

LEgER, A. 1986. Transcurrent faulting history of southern New Brunswick. M.Sc. thesis, University of New Brunswick, Fredericton, New Brunswick, 85 p.

McCutcheon, S.R. and Ruitenbero, A.A. 1987. Geology and mineral deposits, Annidale-Nerepis area, New Brunswick. New Brunswick Department of Natural Resources and Energy, Memoir 2, 137 p.

McKerrow, W.S. and Zieoler, A.M. 1971. The lower Silurian paleo-geography of New Brunswick and adjacent areas. Journal of Geology, 79, pp. 635-646.

McLeod, M.J. 1990. Geology, geochemistry, and related mineral deposits of the Saint George batholith; Charlotte, Queens, and Kings counties, New Brunswick. New Brunswick Department of Natural Resources and Energy, Mineral Resources Division, Report 5, 169 p.

McLeod, M.J. and RAst, N. 1988. Correlations and fault systematics in the Passamaquoddy Bay area, southwestern New Brunswick. Maritime Sediments and Atlantic Geology, 24, pp. 289-300.

NanCE, R.D. and Dallmeyer, R.D. 1993. ${ }^{40} \mathrm{Ar} /{ }^{39} \mathrm{Ar}$ amphibole ages from the Kingston complex, New Brunswick: Evidence for Silurian-Devonian tectonothermal activity and implications for the accretion of the Avalon composite terrane. Journal of Geology, 101, pp. 375-388.

O'Brien, B.H. 1976. The geology of parts of the Coldbrook Group, southern New Brunswick. Unpublished M.Sc. thesis, University of New Brunswick, Fredericton, New Brunswick. $76 \mathrm{p}$.

Payette, C. and Martin, R.F. 1987. The Welsford igneous complex, southern New Brunswick - rift-related Acadian magmatism. In Current Research, Part A, Geological Survey of Canada, Paper 87-1 A, pp. 239-248.

Pearce, J.A. 1983. Role of subcontinental lithosphere in magma genesis at active continental margins. In Continental Basalts and Mantle Xenoliths. Edited by C.J. Hawkesworth and J.J. Norry. Shiv a Press, Cheshire, United Kingdom, pp. 230-249.

Pearce, J.A., Harris, N.B.W., and Tindle, A.G. 1984. Trace element discrimination diagrams for the tectonic interpretation of granitic rocks. Journal of Petrology, 25, pp. 956-983.

Rast, N. and Dickson, W.L. 1982. The Pocologan mylonite zone. Geological Association of Canada, Special Paper 24, pp. 249. 261.

ReYNOLDS, R.C. 1967. Estimation of mass absorption coefficients by Compton scattering: improvements and extensions of the method. American Mineralogist, 52. pp. 1493-1502.

Roddick, J.C. and Bevier, M.L. 1988. Conventional and ion microprobe $\mathrm{U}-\mathrm{Pb}$ ages of two Paleozoic granites, Miramichi terrane, New Brunswick. Geological Association of Canada,
Program with Abstracts, 13, p. A105.

SaCk, R.O., Carmichael, I.S.E, Rivers, M.L., and Ghiorso, M.S. 1980. Ferric-ferrous equilibria in natural silicate liquids at 1 bar. Contributions to Mineralogy and Petrology, 75, pp. 369-376.

SACk, R.O., Walker, D., and Carmichael, I.S.E. 1987. Experimental petrology of alkalic lavas: constraints on cotectics of multiple saturation in natural basic liquids. Contributions to Mineralogy and Petrology, 96, pp. 1-23.

Stockmal, G.S., Colman-Sadd, S.P., Keen, C.E., O'Brien, S.J., and Quinlan, G. 1987. Collision along an irregular margin: a regional plate tectonic interpretation of the Canadian Appalachians. Canadian Journal of Earth Sciences, 24, pp. 1098-1107.

StolPER, E. 1980. A phase diagram for mid-ocean ridge basalts: Preliminary results and implications for petrogenesis. Contributions to Mineralogy and Petrology, 74, pp. 13-27.

Taylor, S.R. and McLennan, S.M. 1985. The Continental Crust: Its Composition and Evolution. Blackwell Scientific Publications, Oxford, 312 p.

Van StaAL, C.R. 1987. Tectonic setting of the Tetagouche Group in northern New Brunswick: Implications for plate tectonic models of the northern Appalachians. Canadian Journal of Earth Sciences, 24, pp. 1329-1351.

VAN StaAl, C.R. and Fypre, L.R. 1991. Dunnage and Gander zones, New Brunswick, Canadian Appalachian region. New Brunswick Department of Natural Resources, Geoscience Report 91-2, 39 p.

WhALEN, J.B. 1993. Geology, petrography and geochemistry of Appalachian granites in New Brunswick and Gaspesie, Quebec. Geological Survey of Canada, Bulletin 436, 117 p.

Whalen, J.B., Currie, K.L., and Chappell, B.W. 1987. A-type granites: geochemical characteristics, discrimination and petrogenesis. Contributions to Mineralogy and Petrology, 95, pp. 407-419.

WiLson, A.D. 1955. A new method for the determination of ferrous iron in rocks and minerals. Bulletin of the Geological Survey of Great Britain, 9, pp. 56-58.

APPENDIX: Location (Fig. 11) and description of analysed specimens.

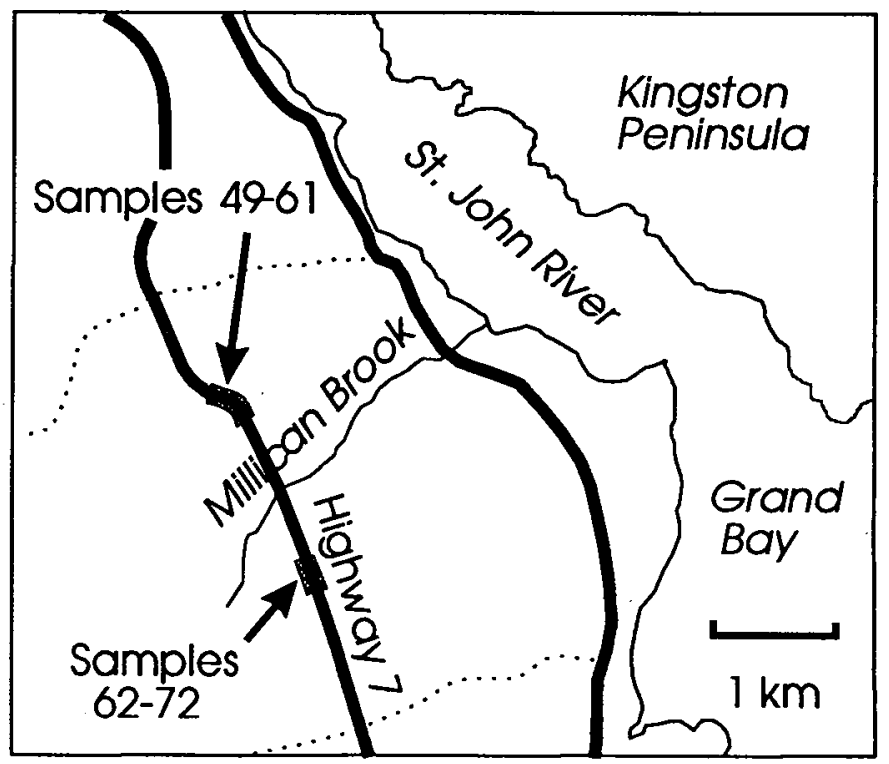

Fig. 11. Location of chemically analysed samples. 
NB49 Fine-grained trachytoid matrix of quartz and feldspar with numerous small, rounded, tabular cloudy twinned albite phenocrysts. Matrix cut by epidote-quartz veinlets.

NB50 Fine-grained albite-actinolite schist with S-C fabric picked out by opaques around cloudy plagioclase phenoclasts and overgrown by less oriented actinolite.

NB51 Fine-grained mylonitic quartz-feldspar matrix with rare tabular phenoclasts, some showing relicts of perthite, wrapped in fine-grained, aligned illitic mica.

NB52 Metagabbro with relict ophitic texture marked by brownish, cloudy plagiolclase and olive actinolite. Prehnite and a pale, younger actinolite are present in small veinlets and vugs.

NB53 Ophitic to trachytic medium-grained amphibolite, with substantial replacement of actinolite by pale chlorite. The texture appears to be relict igneous texture.

NB54 Fine-grained mylonitic quartz-feldspar paste with local nebulous coarser patches and sparse, large tabular feldspar phenoclasts with relict perthitic texture.

NB55 Relict plagioclase laths and actinolite pseudomorphous after pyroxene and olivine? in a fine- to medium-grained matrix which preserves relict igneous texture.

NB56 Fine- to medium-grained quartz-feldspar paste (mylonitic?), with seams and rosettes of actinolite and broken feldspar phenoclasts largely replaced by granular epidote.

NB57 Fine- to medium-grained mylonitic quartz-feldspar paste with rare single or clumped feldspar phenoclasts, some showing relicts of perthitic structure.

NB58 Fine-grained trachytoid matrix of actinolite and chlorite with numerous small, rounded masses of chlorite and badly altered plagioclase (phenocrysts? xenocrysts?).

NB59 Medium-grained relict ophitic texture with twinned, tabular, cloudy plagioclase and irregular actinolite. Local masses of granular epidote occur throughout.

NB60 Metagabbro with tabular pale actinolite rimmed by darker amphibole, and rounded, brownish plagio- clase, rimmed by clear albite. Local epidote porphyroblasts.

NB61 Medium-grained slightly trachytoid texture with aligned, brownish, mosaic plagioclase phenoclasts and less aligned tabular actinolite.

NB62 Trachytoid brownish plagioclase laths with clear albite rims overgrown by arborescent, patchily-zoned actinolite, and small cloudy epidote and sphene prophyroblasts.

NB63 Single and clumped large, square phenocrysts, some with relict Carlsbad and Baveno twins in partly recrystallized granophyric matrix with local granular epidote masses.

NB64 Fine-grained mosaic plagioclase matrix with unoriented tabular actinolite porphyroblasts and a second generation of actinolite needles.

NB65 Medium-grained trachytoid mass of quartz and twinned albite, with rare elongate granular epidote clumps. This appears to be slightly modified igneous texture.

NB66 Clumps of large tabular to square feldspar phenocrysts, commonly perthitic, in a granular matrix with local traces of granophyric texture.

NB67 Matrix of medium-grained brown, altered plagioclase laths, overgrown by unoriented tabular actinolite porphyroblasts.

NB68 Single and clumped large, square to tabular phenocrysts, some with relict Carlsbad and Baveno twins in partly recrystallised granophyric matrix with local granular epidote masses.

NB69 Fine-grained mosaic plagioclase matrix with oriented ragged actinolite porphyroblasts. A few rounded, badly altered tabular feldspar phenoclasts occur.

NB70 Medium-grained mosaic feldspar-quartz paste with rather sparse relict albite phenocrysts and minute, oriented actinolite porphyroblasts in the matrix.

NB71 Medium-grained ophitic textured matrix with brown, altered plagioclase and ragged actinolite containing a few large, tabular, altered, plagioclase phenocrysts.

NB72 Single and clumped large, square to tabular phenocrysts, some with relict Carlsbad and Baveno twins in partly recrystallised granophyric matrix with local granular epidote masses. 